\title{
Cortical-Like Receptive Fields in the Lateral Geniculate Nucleus of Marmoset Monkeys
}

\author{
Soon Keen Cheong, ${ }^{1,2}$ Chris Tailby, ${ }^{3,4}$ Samuel G. Solomon, ${ }^{1,4,5}$ and Paul R. Martin ${ }^{1,2,4}$ \\ ${ }^{1}$ ARC Centre of Excellence in Vision Science, The University of Sydney Eye Hospital Campus, Sydney, New South Wales 2001, Australia, ${ }^{2}$ Save Sight \\ Institute, The University of Sydney Eye Hospital Campus, Sydney, New South Wales 2001, Australia, ${ }^{3}$ Florey Institute of Neuroscience and Mental Health, \\ Melbourne Brain Centre, Heidelberg, Victoria 3084, Australia, ${ }^{4}$ Discipline of Physiology, The University of Sydney, Sydney, New South Wales 2006 , \\ Australia, and ${ }^{5}$ Research Department of Cognitive, Perceptual and Brain Sciences, University College London, London WC1 0AH, United Kingdom
}

Most neurons in primary visual cortex (V1) exhibit high selectivity for the orientation of visual stimuli. In contrast, neurons in the main thalamic input to V1, the lateral geniculate nucleus (LGN), are considered to be only weakly orientation selective. Here we characterize a sparse population of cells in marmoset LGN that show orientation and spatial frequency selectivity as great as that of cells in V1. The recording position in LGN and histological reconstruction of these cells shows that they are part of the koniocellular (K) pathways. Accordingly we have named them K-o ("koniocellular-orientation") cells. Most K-o cells prefer vertically oriented gratings; their contrast sensitivity and TF tuning are similar to those of parvocellular cells, and they receive negligible functional input from short wavelength-sensitive ("blue") cone photoreceptors. Four K-o cells tested displayed binocular responses. Our results provide further evidence that in primates as in nonprimate mammals the cortical input streams include a diversity of visual representations. The presence of K-o cells increases functional homologies between $\mathrm{K}$ pathways in primates and "sluggish/W" pathways in nonprimate visual systems.

\section{Introduction}

The majority of receptive fields in primary visual cortex (V1) show high selectivity for the orientation and/or drift direction of visual stimuli (Henry et al., 1974; Hubel and Wiesel, 1977; De Valois et al., 1982). In contrast, receptive fields in the major input to V1 (the dorsal lateral geniculate nucleus, LGN), are customarily described as circular, displaying at most only weak orientation bias. Examples of orientation bias in the response of LGN neurons have been reported for macaque and marmoset monkey (Lee et al., 1979; Smith et al., 1990; White et al., 2001), the nocturnal monkey Aotus (Xu et al., 2002), and cat (for review, see Shou and Leventhal, 1989). Orientation bias naturally emerges when high spatial frequencies are used to probe any receptive field that is not circular, because the short axis of a noncircular receptive field can "see" higher spatial frequencies than the long axis (Levick and Thibos, 1982; Vidyasagar and Urbas, 1982; Leventhal and Schall, 1983; Soodak et al., 1987; Passaglia et al., 2002). Such bias is manifest as broad tuning for the orientation of gratings presented at spatial frequency (SF) above optimal for the receptive field.

\footnotetext{
Received Nov. 8, 2012; revised Feb. 7, 2013; accepted March 2, 2013.

Author contributions: S.K.C., S.G.S., and P.R.M. designed research; S.K.C., C.T., S.G.S., and P.R.M. performed research; S.K.C., C.T., S.G.S., and P.R.M. analyzed data; S.K.C. and P.R.M. wrote the paper.

This work was supported by Australian National Health and Medical Research Council grants 566558 and 511967. We thank E.M. Blessing, P. Buzás, A.N.J. Pietersen, A. J. Camp, and B. Szmajda for helping to collect the data; A. Lara and A. Demir for technical assistance; and W. Dobbie for computer programming.

Correspondence should be addressed to Paul RMartin, Save Sight Institute C09, The University of Sydney, Sydney, NSW 2006, Australia. E-mail: prmartin@sydney.edu.au.

DOI:10.1523/JNEUROSCI.5208-12.2013

Copyright $\odot 2013$ the authors $\quad 0270-6474 / 13 / 336864-13 \$ 15.00 / 0$
}

Here we characterize a rare population of LGN cells showing orientation and SF selectivity that is comparable to that of cells in $\mathrm{V} 1$. These neurons are likely part of the koniocellular $(\mathrm{K})$ pathway from retina to visual cortex, not part of the main parvocellular (P) and magnocellular (M) afferent streams.

The question if cortical afferent streams include orientationselective receptive fields is important for two reasons. First, in the hierarchical model of vision, analysis of the shape of visual objects begins with the generation of orientation selectivity by circuits in V1 (Hubel and Wiesel, 1977; Mishkin et al., 1983; Lennie and Movshon, 2005). Under this view, orientation- and directionselective receptive fields in retina are of relevance only to subcortical visual pathways that control reflex eye movements. Orientation selectivity in cortical afferent pathways would instead support diversity of visual representation at early levels of visual processing in primates.

The second reason to study orientation selectivity in LGN concerns the functional roles of $\mathrm{K}$ pathways. The $\mathrm{K}$ layers of the LGN are known to target superficial layers of V1 as well as extrastriate visual areas (Yukie and Iwai, 1981; Fitzpatrick et al., 1983; Lachica and Casagrande, 1992; Casagrande, 1994; Sincich et al., 2004), but receptive fields of K pathways remain poorly understood. Established components of $\mathrm{K}$ pathways in macaque and marmoset monkeys include color-coded ("blue-On" and "blue-Off") and "suppressed by contrast” receptive fields (White et al., 1998; Szmajda et al., 2006; Solomon et al., 2010). Delineating further functional groups among K pathways will help to characterize the sensory inputs to the cerebral cortex, and will test proposed functional homologies of primate K pathways to "sluggish/W" pathways in nonprimate mammals (Irvin et al., 1986). 


\section{Materials and Methods}

Experimental procedures conformed to the Australian National Health and Medical Research Council codes of practice for the use and care of animals and were approved by institutional animal care and ethics committees at the University of Sydney and the University of Melbourne. The responses described here are from receptive fields encountered in recordings from a main series of 28 adult marmosets (Callithrix jacchus, body weight 360-475 g; 17 male, 11 female). Nine examples of "koniocellularorientation" (K-o) receptive fields were encountered in eight of these animals. (We present hereinafter the evidence that K-o cells are part of koniocellular pathways). Responses of one cell that were previously published (White et al., 2001, their Fig. 9A) were reanalyzed. For normative purposes, responses of P cells $(n=129)$, M cells $(n=110)$, and koniocellular blue-On cells (K-bon, $n=25$ ) recorded from the main series animals under (as close as possible) identical stimulus and recording conditions were reanalyzed for the present study. Normative data from V1 were taken from recordings made in an additional four animals. Some of the normative data were previously published (Hashemi-Nezhad et al., 2008; Tailby et al., 2008b; Solomon et al., 2010); all responses were reanalyzed for the present study.

Recording procedures. Marmosets were initially anesthetized either with intramuscular ketamine $\left(30 \mathrm{mg} \mathrm{kg}^{-1}\right.$; Therapon) or alfaxalone $(12 \mathrm{mg}$ $\mathrm{kg}^{-1}$; Alfaxan). Subsequent surgery was performed under supplemental local anesthesia (Lignocaine 2\%; AstraZeneca) and supplemental doses of anesthetic as required. The femoral or tail vein was cannulated to allow the administration of fluids and drugs. A tracheostomy was performed for artificial respiration of the animal with a mixture of $70 \% \mathrm{NO}_{2}$ and $30 \%$ carbogen $\left(5 \% \mathrm{CO}_{2}: 95 \% \mathrm{O}_{2}\right)$. The animal was placed in a stereotaxic frame and a craniotomy was made over the LGN or V1. Gas-permeable contact lenses were used to protect the corneas.

Postsurgical anesthesia was maintained throughout the experiment using an intravenous infusion of sufentanil citrate $\left(6-12 \mu \mathrm{g} \mathrm{kg}^{-1} \mathrm{~h}^{-1}\right.$; Sufenta Forte, Janssen-Cilag). Muscular relaxation was maintained with pancuronium bromide $\left(0.24 \mathrm{mg} \mathrm{kg}^{-1} \mathrm{~h}^{-1}\right.$; AstraZeneca) in Hartmann's solution containing glucose $(5 \%)$ with added dexamethasone $(0.4 \mathrm{mg}$ $\mathrm{kg}^{-1} \mathrm{~h}^{-1}$; Mayne Pharma) and Synthamin 17 (225 $\mathrm{mg} \mathrm{kg}^{-1} \mathrm{~h}^{-1}$; Baxter International). Body temperature was kept near $38^{\circ} \mathrm{C}$ using a homeostatic blanket controlled via a rectal probe. End tidal $\mathrm{CO}_{2}$ was maintained near $33 \mathrm{mmHg}$ by adjusting the rate and volume of ventilation.

Electroencephalogram (EEG) and electrocardiogram signals were monitored to ensure adequate depth of anesthesia. The EEG signal was subjected to Fourier analysis. Dominance of low frequencies $(1-5 \mathrm{~Hz})$ in the EEG recording, and absence of EEG changes under noxious stimulus (tail pinch) were taken as the chief sign of an adequate level of anesthesia. We found that low dose rates in the range cited above were always very effective during the first $24 \mathrm{~h}$ of recordings. Thereafter, drifts toward higher frequencies $(5-10 \mathrm{~Hz})$ in the EEG record were counteracted by increasing the rate and/or concentration of sufentanil in the venous infusion. The typical duration of a recording session was 72-96 h.

Recordings were made with single electrodes (stainless steel, 9-11 $\mathrm{M} \Omega, \mathrm{FHC}$ ) or tetrodes (Thomas Recording). Neuronal signals were amplified, bandpass filtered $(0.3-10 \mathrm{kHz})$, and fed into a Power Mac G5 running data acquisition software (Expo, P. Lennie). Multiple cells recorded simultaneously using a single electrode or tetrode array were isolated using real-time principle component analysis. Spike events were recorded with an accuracy of $0.1 \mathrm{~ms}$. Off-line analysis was performed using MATLAB (MathWorks).

Visual stimuli. A front-silvered mirror was used to bring the receptive field onto the center of a calibrated cathode ray tube monitor (ViewSonic G810 or Sony G520, refresh rate $80-100 \mathrm{~Hz}$; mean luminance $40-60$ candela $\mathrm{m}^{-2}$; viewing distance $114 \mathrm{~cm}$ ). Visual stimuli were drawn with 8 -bit resolution using commands to OpenGL. The stimulus was a drifting sinusoidal grating or a uniform field modulated in time; all stimuli modulated around the mean luminance and were presented within a circular window with hard edges (diameter usually $8^{\circ}$ ); outside this window the screen luminance was held at the grating mean. Refraction was optimized using the first encountered $\mathrm{P}$ receptive fields, by measuring responses to drifting gratings and selecting supplemental lenses that maximized cells' spatial resolution. Unless otherwise stated, the nondominant eye was occluded.

Receptive field position and stimulus selectivity were initially mapped using small patches of drifting grating. Michelson contrast was 0.5 or the maximum achievable ("1.0") and temporal modulation frequency was 5 $\mathrm{Hz}$ unless otherwise stated. Spatial-frequency tuning curves were obtained for gratings at orientation determined during the initial mapping. Orientation tuning was measured for drifting gratings at optimum spatial frequency; responses were measured for each of eight orientations drifting in each of two directions $\left(0-337.5^{\circ}\right.$ in $22.5^{\circ}$ steps $)$. Temporal frequency (TF) tuning curves were obtained at optimum SF and orientation. Contrast response was obtained for gratings of optimum spatial and TF, and orientation. Response was obtained for at least three repetitions of each stimulus, presented in pseudorandom order every 2-6s. Each trial lasted 1-5 s; between trials the monitor was held at the mean luminance for $1 \mathrm{~s}$.

The strength of input from short wavelength-sensitive (S)-cones was established from responses to square-wave modulation $(0.5 \mathrm{~Hz})$ of a uniform field that either modulated all cone types (achromatic) or produced selective modulation of the S-cones. Receptive fields showing greater response amplitude to S-cone modulation than to achromatic modulation were further characterized using S-cone-selective gratings. The S-cone-selective gratings were produced as described in our detailed studies of K-bon receptive fields (Szmajda et al., 2006; Tailby et al., 2008b).

Analyses. Peristimulus time histograms (PSTHs) were subjected to Fourier analysis, whence we obtained response amplitude at the modulation frequency of the stimulus (F1). Cells were classified as "simplelike" if the maximum F1 amplitude was greater than the maximum elevation in mean rate (Skottun et al., 1991). All P, M, and K-bon cells showed simple-like response signature.

For K-o cells, the larger of the F0 or F1 component of the response was used as the responsivity measure. For P, M, and K-bon cells the F1 amplitude was used. The F1 amplitude was used for V1 simple cells and the F0 amplitude was used for V1 complex cells.

Orientation selectivity was quantified by taking the ratio of the vector sum of the orientation tuning responses over the scalar sum of responses (Levick and Thibos, 1982). The response $R$ to a grating drifting in a particular direction is represented by vector in complex space with a magnitude of $r\left(\mathrm{imp} \mathrm{s}^{-1}\right.$ ) and inclined at the angle of $\theta$ (radians) by the equation $R=r e^{i 2 \theta}$. A bias vector $B$ was then calculated as the sum of response vectors divided by the sum of response magnitudes at 16 orientations tested:

$$
B=b e^{i 2 \theta_{p}}=\frac{\sum R}{\sum r}
$$

The magnitude of the bias vector $B$ represents the magnitude of orientation bias, termed the orientation selectivity index (OSI). The OSI varies from 0 to 1 , where 0 indicates equal response to all orientations and 1 indicates response to only one orientation. We use OSI in preference to circular variance ( 1 - OSI) because larger OSI values imply greater response specificity. The angle $\theta_{p}$ is the "preferred " orientation (orientation of a grating yielding the maximum response). Direction selectivity was quantified in a similar manner, without doubling the angular component $\left(R=r e^{i \theta}\right)$. Orientation tuning bandwidth was established by finding the best predictions of a wrapped normal function (Mardia and Jupp, 2000; Dakin et al., 2005) using the function lsqcurvefit in the MATLAB environment.

SF selectivity was quantified by fitting the SF tuning curve with a difference of Gaussian (DOG) model (Enroth-Cugell and Robson, 1966; Croner and Kaplan, 1995):

$$
R=C\left[\left(K_{c} \pi r_{c}^{2} e^{-\left(\pi r_{c} f\right)^{2}}\right)-\left(K_{s} \pi r_{s}^{2} e^{-\left(\pi r_{s} f\right)^{2}}\right)\right]
$$

where $R$ is response amplitude (imp s ${ }^{-1}$ ), $C$ is Michelson contrast of the stimulus, and $f$ is the SF of the stimulus $\left(\mathrm{cyc} \mathrm{deg}^{-1}\right)$. The free parameters $\left(K_{c}\right.$, center sensitivity; $r_{c}$, center radius; $K_{s}$, surround sensitivity; $r_{s}$, surround radius) were optimized using the nlsqfit function in MATLAB 
(MathWorks). SF selectivity was characterized from the DOG fits as follows:

$$
S F I=1-\frac{r_{L}}{r_{p}}
$$

Where SFI is SF selectivity, $r_{L}$ is response amplitude to the lowest SF presented $\left(0.01 \mathrm{cyc} \mathrm{deg}^{-1}\right)$, and $r_{P}$ is the peak response amplitude. A SF selectivity value $L=1$ indicates complete bandpass SF tuning (no response at low SF) and a value $L=0$ indicates low-pass tuning.

Contrast gain was quantified by fitting the contrast tuning curve with a saturating hyperbolic ("Naka-Rushton") function (Naka and Rushton, 1966):

$$
R=R_{0}+R_{\max } \frac{c}{c_{50}+c}
$$

where $R$ is response amplitude, $c$ is stimulus contrast, $R_{0}$ is the maintained firing rate in absence of spatial contrast (minimum discharge rate), $R_{\max }$ is the maximum or plateau response, and $c_{50}$ is the contrast at half maximum response. The $c_{50}$ was taken to estimate contrast gain and was constrained with an upper limit of two; $c_{50}$ above unity indicates linear contrast tuning.

Linear prediction of orientation selectivity. Previous work showed circular anisotropy in subcortical receptive field centers can produce orientation bias for high SF gratings (Levick and Thibos, 1982; Vidyasagar and Urbas, 1982; Leventhal and Schall, 1983; Soodak et al., 1987; Passaglia et al., 2002). We therefore asked how much orientation bias would be expected if the receptive field center was elongated using a simple modification to the standard DOG model. We predicted how OSI would depend on receptive field aspect ratio (major-to-minor axis ratio) and stimulus $\mathrm{SF}$, using parallel methods to those outlined above for characterizing SF and orientation selectivity. The receptive field center was modeled as a $2 \mathrm{D}$ Gaussian spatial weighting function with varying aspect ratio:

$$
R_{c}=f(x, y)=\exp \left(-\left(\frac{\left(x-x_{0}\right)^{2}}{2 \sigma_{x}^{2}}+\frac{\left(y-y_{0}\right)^{2}}{2 \sigma_{y}^{2}}\right)\right)
$$

where $R_{c}$ is the center response, $x$ and $y$ are spatial coordinates on the major and minor ellipse axes, $x_{0}$ and $y_{0}$ are the coordinates of the receptive field center, and $\sigma_{x}, \sigma_{y}$, are the major and minor axis SD. The surround was modeled as a circular Gaussian:

$$
R_{s}=f(x, y)=\exp \left(-\left(\frac{\left(x-x_{0}\right)^{2}}{2 \sigma_{s}^{2}}+\frac{\left(y-y_{0}\right)^{2}}{2 \sigma_{s}^{2}}\right)\right)
$$

where $R_{s}$ is the surround response, $\sigma_{s}$ is the surround $\mathrm{SD}$, and other symbols are as in Equation 5. The cell response was set as the difference of center and surround responses:

$$
R=R_{c}-k R_{s}
$$

where $R$ is the cell response, $R_{c}$ is the center response (Eq. 5), $R_{s}$ is the surround response (Eq. 6), and $k$ is the relative peak strength of the surround. The SD of the of the surround was set to three times that of the major axis of the center, and the surround weight $k$ was set to 0.02 . Center and surround were concentric. Response was the dot product of the receptive field and a synthetic grating of variable SF, orientation, and phase. Response amplitude was calculated by presenting 16 sequential phases spanning 360 degrees, then fitting a sine curve to the model cell responses. The peak SF and OSI were calculated as a function of the aspect ratio of the receptive field center. For simplicity we used model receptive field parameters based on averages for $\mathrm{P}$ and $\mathrm{M}$ cells in our previous studies (Buzás et al., 2006; Tailby et al., 2010); we did not undertake a more extensive exploration of the model parameter space (e.g., Tailby et al., 2010).

To compare the simulations with recordings from real neurons, we calculated relative SF (that is, the ratio of SF at which orientation bias was measured, to the preferred SF determined from the frequency tuning curve). For example, a relative SF of 2 indicates that orientation bias (OSI) was measured at twice the cell's optimum SF. For simulations,
A

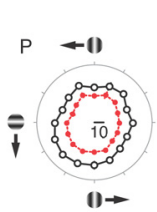

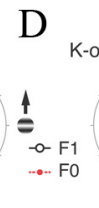
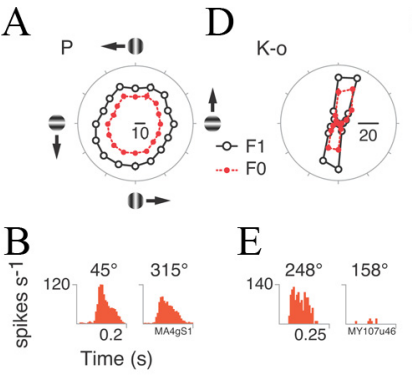

$\mathrm{E}$

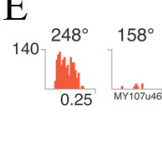

G

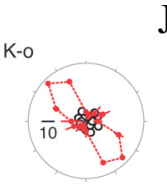

V1

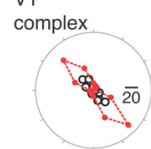

$\mathrm{H}$

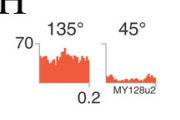

$\mathrm{K}_{150}{ }_{135^{\circ}} 45^{\circ}$
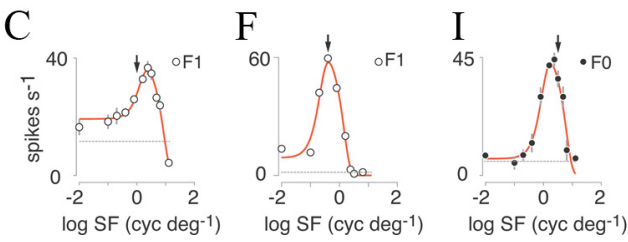

L

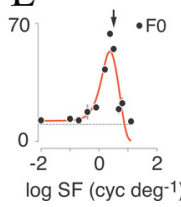

Figure 1. Orientation and SF tuning of geniculate and cortical neurons. $A-C, P$ cell. Top row $(A)$, Orientation tuning curve of mean (F0) and fundamental harmonic (F1) responses. Gratings and arrows in $\boldsymbol{A}$ illustrate the stimuli presented on the monitor. (enter row (B), PSTH folded to one cycle of the grating. Values above the PSTH indicate orientation of drift. Left, PSTH shows responses to optimal orientation. Right, PSTH shows orthogonal to optimal orientation. The P cell responds in phase to the stimulus. Lower row $(C)$, SF tuning curve fit with the DOG model. The arrow indicates the SF at which the orientation tuning curve was measured. $\mathbf{D}-\boldsymbol{F}$, Orientation-selective cell responses, in the same format as $\boldsymbol{A}$-C. This cell shows "simple-like" behavior with pronounced phase-locked F1 response $(\boldsymbol{B})$. $\mathbf{G}-\boldsymbol{I}$, Second example of a K-0 cell; this cell shows "complex-like" behavior with increased average firing ( $\mathrm{F} 0)$ for preferred orientations. $J-L$, Complex cell in primary visual cortex (V1). Note that the K-o cells and the complex cell show strong bandpass spatial tuning $(\boldsymbol{F}, \boldsymbol{I}, \boldsymbol{L})$ and feeble responses to gratings drifting orthogonal to the preferred orientation $(\boldsymbol{E}, \boldsymbol{H}, \boldsymbol{K})$. Error bars on graphs indicate SEM. Error bars are present at all data points but some are smaller than the point symbols.

optimal SF was measured for gratings at optimal orientation. For real neurons, optimal SF is poorly constrained in neurons showing low-pass SF tuning. In these neurons orientation tuning was normally measured for a SF slightly above the high-frequency corner. The upshot of this strategy is that for low-pass cells the relative SF appears high.

Statistical comparisons. Unless otherwise stated, Kruskal-Wallis nonparametric one-way ANOVA is used to determine significant differences between groups. Post hoc comparison ( $F$ statistic) is used to quantify group differences. Circular statistics were calculated with open source MATLAB toolbox functions CircStat (Berens, 2009).

Cluster analysis. Principal components and $k$-mean cluster distances were calculated from $z$-transformed receptive field parameters using the princomp and kmean functions in MATLAB statistics toolbox (MathWorks). The $k$-mean cluster distance was calculated from the first and second principal component weights with 10 replicates.

Histology. The depth of each cell relative to the brain surface was recorded from a hydraulic microdrive (David Kopf Model 640). Electrolytic lesions (3-6 $\mu \mathrm{A} \times 3-6 \mathrm{~s}$, electrode positive) were made to assist in track reconstruction. At the conclusion of recordings the animal was killed with an overdose of pentobarbitone sodium $\left(80-150 \mathrm{mg} \mathrm{kg}^{-1}\right.$, i.v.) and perfused with $250 \mathrm{ml}$ of saline $(0.9 \% \mathrm{NaCl})$ followed by $300 \mathrm{ml}$ of $4 \%$ paraformaldehyde in $0.1 \mathrm{~m}$ phosphate buffer $(\mathrm{PB}, \mathrm{pH} 7.4)$. The brain was removed and placed in glycerol solution $(20 \%$ in $0.1 \mathrm{M} \mathrm{PB})$. Coronal sections at $50 \mu \mathrm{m}$ thickness were cut on a freezing microtome, mounted onto glass slides, and air dried. Alternative sections were stained with cresyl violet to reveal the layers of the LGN, or left unstained to reveal electrode tracts and lesions visible by autofluorescence. The position of recorded cells was reconstructed by identifying the electrolytic lesions and tracks, and correlating changes in eye dominance with the laminar pattern revealed by the cresyl violet stain.

\section{Results}

Orientation and SF tuning

Figure 1 shows orientation (upper row) and SF (lower row) tuning curves for three example cells in LGN and one example cell in 
V1. Orientation tuning was measured at an SF close to that preferred by the neuron, as indicated by arrows on the SF tuning curves. The center row in Figure 1 shows PSTHs folded to a single cycle of drift, for optimal and orthogonal orientations. As is typical of neurons in the LGN, the P neuron responds nearly equally to all orientations (Fig. $1 A, B$ ) and shows mild bandpass SF tuning (Fig. $1 C$ ), and responds in a phase-locked manner to drifting gratings (Fig. 1B). These properties of $\mathrm{P}$ cells are well established (Hicks et al., 1983; Smith et al., 1990; Usrey and Reid, 2000; Solomon et al., 2002; Lennie and Movshon, 2005).

Figure $1, D-I$, illustrates the very different behavior of two cells in marmoset LGN with strong orientation (Fig. $1 D, G$ ) and SF (Fig. 1F,I) selectivity. For both the examples shown, responses to gratings with the same orientation but opposite drift directions have similar magnitude, indicating selectivity for orientation but not direction. This behavior is similar to that of orientation-selective cells in V1, as shown by responses of a V1 complex cell to the same stimuli (Fig. $1 I-L$ ). Responses of one of the orientation-tuned LGN cells (Fig. $1 E$ ) are tightly phase locked to the stimulus cycle. Five of nine (56\%) K-o cells showed comparable linear (simple/X-like) spatial summation. The other cells showed nonlinear (complex/Y-like) responses to drifting gratings; in common with the example shown here (Fig. 1H) they responded with elevated mean discharge to drifting gratings.

We show in the following sections that these orientationselective and SF-selective receptive fields are likely part of the $\mathrm{K}$ visual pathways, and for this reason we call them K-o (koniocellular-orientation) cells. The K-o cells presented here were recorded in 8 from a series of 28 marmosets. As explained below (see Discussion) this low encounter rate may underestimate the true proportion of K-o cells.

\section{Orientation selectivity}

Figure 2 compares orientation selectivity in LGN and V1 populations. As explained above (see Materials and Methods) OSI $=0$ indicates no selectivity for orientation; OSI $=1$ indicates responses to only one of the tested orientations. For K-o cells, minimum and maximum OSI were 0.37 and 0.63 . For other LGN cells, the range of OSI was as follows: $\mathrm{P}, 0.004-0.27$; M, 0.0020.25; and K-bon, 0.02-0.17. The distributions of OSI for M, P, and K-bon cells are consistent with previous reports of LGN neurons where OSI was measured at or near the preferred SF (Smith et al., 1990; Xu et al., 2002; Forte et al., 2005). The OSI for V1 simple cells ranged from $0.02-0.90$, and for complex cells from $0.06-0.92$. Orientation selectivity in K-o cells was observed using stimuli that evoked vigorous $\left(>20 \mathrm{imp} \mathrm{s}^{-1}\right.$ ) responses (Fig. $1 D-$ I). We used F0 amplitude as response metric for "complex-like" $\mathrm{K}-\mathrm{o}$ cells and F1 as response metric for "simple-like" K-o cells. Indistinguishable results were obtained on recalculation using F0 as the response metric for all K-o cells ( $p=0.53$, Wilcoxon ranksum test). One K cell with an OSI above the range of $\mathrm{P}$ and $\mathrm{M}$ cells was partially characterized (Fig. $2 C$, gray bar). This cell was a $\mathrm{K}$ cell recorded simultaneously with a K-bon cell; responses of this cell were not analyzed further.

The orientation tuning curves of each K-o cell show response minima that lie at (or below) the maintained rate (Fig. $1 D, G$ ). The maintained discharge rate for $\mathrm{K}$-o cells was $4.18 \pm 4.23$ spikes $\mathrm{s}^{-1}$ (mean $\left.\pm \mathrm{SD}, n=9\right)$. Mean direction selectivity index (DSI; Levick and Thibos, 1982) of K-o cells was low (0.06 \pm 0.07 , $n=9)$. The maximum DSI measured was 0.22 . We conclude that the orientation selectivity of $\mathrm{K}$-o cells is substantially higher than that of other LGN cells and is comparable to that of V1 cells.

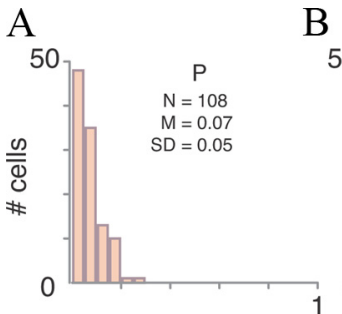

B

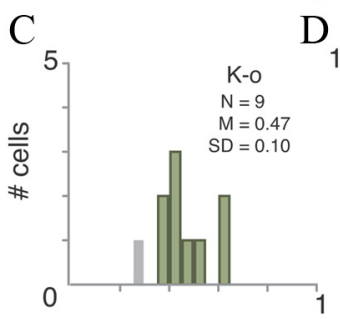

D

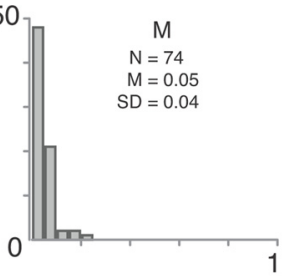

$\mathrm{E}$

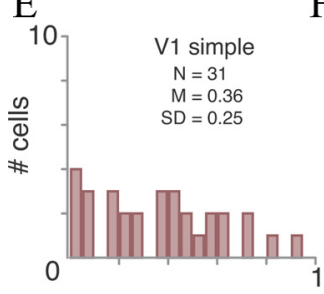

F

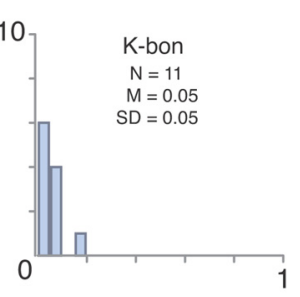

Orientation selectivity

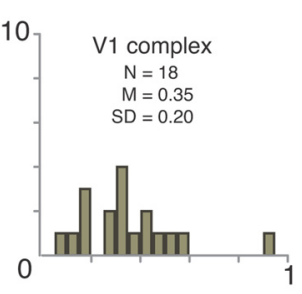

Orientation selectivity

Figure 2. Distribution of orientation selectivity of geniculate and cortical cells. A, P cells. B, M cells. C, K-o cells. The gray bar shows a cell recorded in a Klayer simultaneously with a K-bon cell. D, K-bon cells. E, Primary visual cortex (V1) simple cells. $\boldsymbol{F}$, V1 complex cells. Orientation selectivity for K-bon cells was calculated from S-cone-isolating gratings. Orientation selectivity for all other cells was calculated from achromatic drifting gratings. Note the overlap in orientation selectivity between $\mathrm{K}-\mathrm{o}$ and $\mathrm{V} 1$ cells.

\section{Preferred orientation}

Many P and M cells in macaque LGN (Smith et al., 1990) and retina (Passaglia et al., 2002) show orientation bias for radially oriented gratings; there is also evidence that $\mathrm{P}$ cell receptive fields are elongated on the horizontal axis (Smith et al., 1990). We therefore asked whether the preferred orientation of K-o cells aligns with any visual field axis. When orientation tuning curves of $\mathrm{K}$-o cells are projected onto their visual receptive field position (Fig. 3A) it is apparent that the majority of $\mathrm{K}$-o tuning curves are aligned close to the vertical axis (OSI-weighted Rayleigh statistic $=0.49$, mean angle $\left.81^{\circ}, \mathrm{SD} \pm 57.6, p=0.04, n=9\right)$. No significant alignment relative to the radial or tangential retinal axes is evident $(r>0.25, p>0.5)$. The reader should note that these statistical tests have different levels of stringency. Estimates of radial/tangential bias are made relative to foveal position, and thus are sensitive to estimate errors and drift in eye position (Smith et al., 1990). Estimates of vertical bias are made relative to stimulus orientation and are not dependent on any retinal landmark. Randomly selected examples of tuning curves for $\mathrm{P}, \mathrm{M}$, K-bon, and V1 cells are shown in Figure 2B. Consistent with results from macaque $\mathrm{LGN}$, the $\mathrm{P}$ population shows preference for horizontal oriented gratings (OSI-weighted Rayleigh statistic $=0.30$, mean angle $\left.0.6^{\circ} \pm 67.8, p<0.01, n=151\right)$, but the $\mathrm{P}$ cells in marmosets do not show radial or tangential bias $(r=0.10$, $p=0.29)$. No clustering of preferred orientation, radial or tangential bias ( $p>0.2$ for all tests) was evident for M cells $(n=97)$, $\mathrm{K}$-bon cells $(n=16)$, or V1 cells $(n=49)$. These data indicate that $\mathrm{K}$-o receptive fields are preferentially aligned to the vertical visual axis, but (as explained above) a larger cell sample would be required to rule out the alternative possibility of radial bias. 


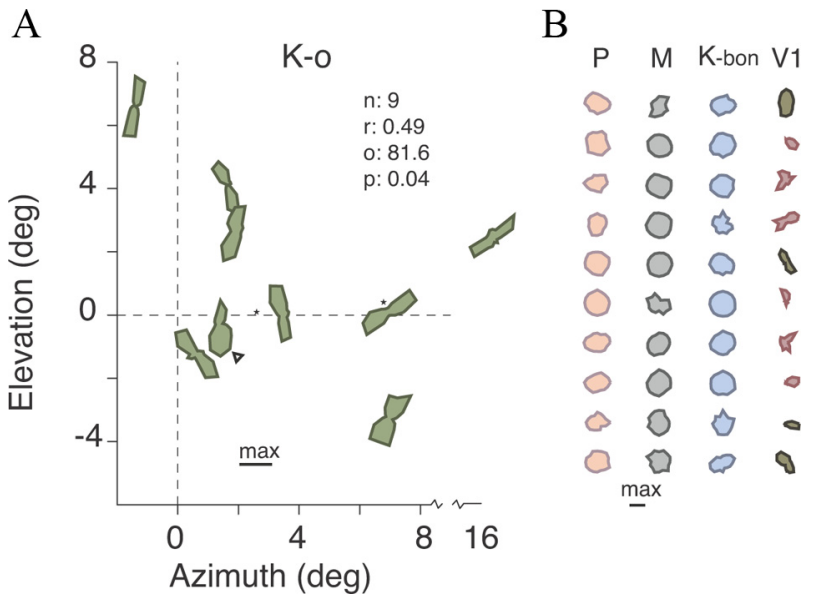

Figure 3. Orientation tuning and visual field location. $\boldsymbol{A}$, Visual field map showing tuning curves (polar plots) of $\mathrm{K}-0$ cells. The center of each tuning curve is plotted at the visual field coordinates of the recorded cell. The curve of one K-o cell is displaced for clarity (asterisk). One cell (arrowhead) was recorded from the right LGN. The elongation on the $y$-axis of each tuning curve indicates greater responsivity to vertical orientations. Note that six of nine $\mathrm{K}-0$ cells prefer vertical orientations. n, number of cells; $r$, Rayleigh coherence of preferred orientations, 0 , mean of preferred orientations; $p$, probability value of Rayleigh coherence. Preferred direction was weighted by orientation selectivity for each cell in the coherence vector sum. $\boldsymbol{B}$, Randomly selected samples of tuning curves of $\mathrm{P}, \mathrm{M}, \mathrm{K}$-bon, and primary visual cortex (V1) cells. Note lack of strong tuning in $\mathrm{P}$ and $\mathrm{M}$ cells and lack of coherent preferred direction in $\mathrm{V} 1$ cells.

\section{Linear prediction of orientation bias}

Although the orientation selectivity of K-o cells is higher than that of $\mathrm{P}$ and $\mathrm{M}$ cells, it could nevertheless, in principle, be explained by stimulation of mildly elliptic receptive fields with high SFs (Levick and Thibos, 1982; Leventhal and Schall, 1983; Soodak et al., 1987; Chapman et al., 1991). Figure $4 A$ shows by computational analysis that this possibility can be ruled out. The contour lines show linear predictions of OSI as a function of SF, for drifting gratings presented to center-surround receptive fields of variable ellipticity. Superimposed on this parameter space are our measures of orientation selectivity for K-o cells, P cells, and M cells. The $x$-axis shows relative SF; that is, the SF at which orientation tuning was measured, divided by the preferred SF at the preferred orientation. Responses of the majority (7/9) of K-o cells can only be explained by the linear prediction if the receptive field aspect ratio (major/minor axis) is greater than four. In contrast, orientation tuning in the majority of $\mathrm{P}$ cells $(50 / 73,67 \%)$ and nearly all $\mathrm{M}$ cells $(57 / 65,88 \%)$ can be explained by receptive field centers having an aspect ratio below two.

For two K-o cells we were able to compare the orientation tuning measured using drifting gratings to a linear prediction based on receptive field mapping via white noise stimulation Responses were measured using 16 by 16 checkerboard elements, with intensity randomly drawn from a Gaussian distribution, and updated every $30 \mathrm{~ms}$ (Chichilnisky, 2001; Solomon et al., 2010). Figure $4 B$ shows one frame of the spike-triggered average (STA) for each of these cells, which reveals distinct On- and Offsubregions in the receptive field. The temporal kernels of the Onand Off-subregions show initial peaks close to $50-60 \mathrm{~ms}$ implied latency (Fig. 4C) indicating similar temporal processes contribute to the two subregions. From these data we derived a linear prediction of orientation tuning, by convolving the STA with synthetic gratings drifting at the spatial and temporal frequencies used to measure orientation tuning (see Materials and Methods). The predicted orientation tuning is broadly consistent with the measured orientation tuning (Fig. $4 D$ ), implying substantially
A

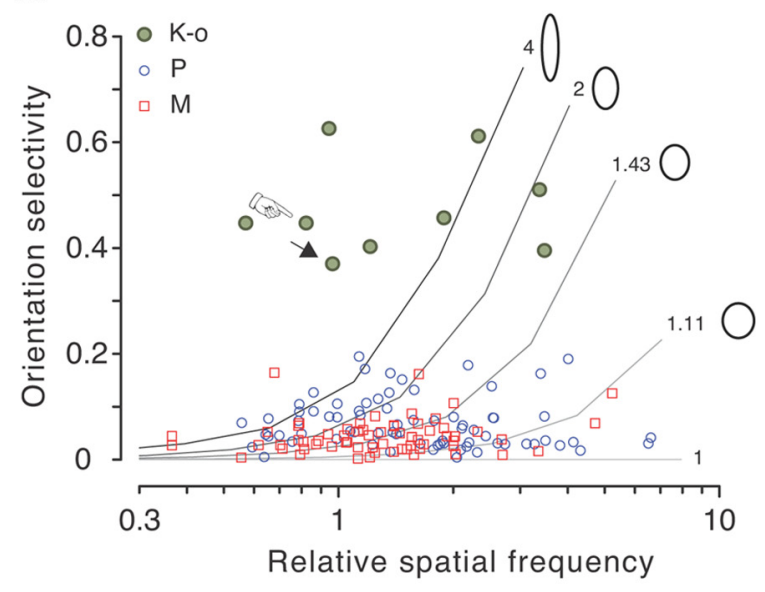

B
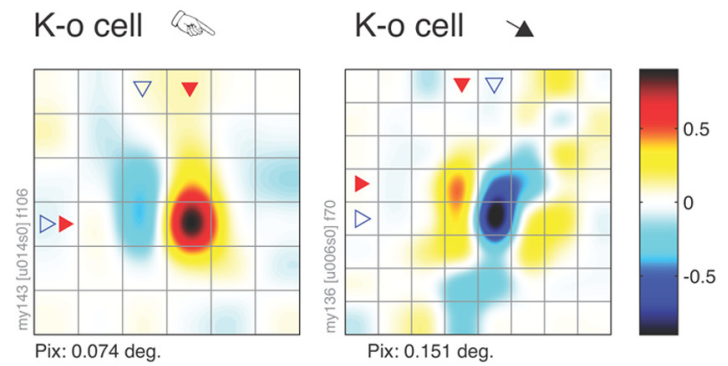

$\mathrm{C}$
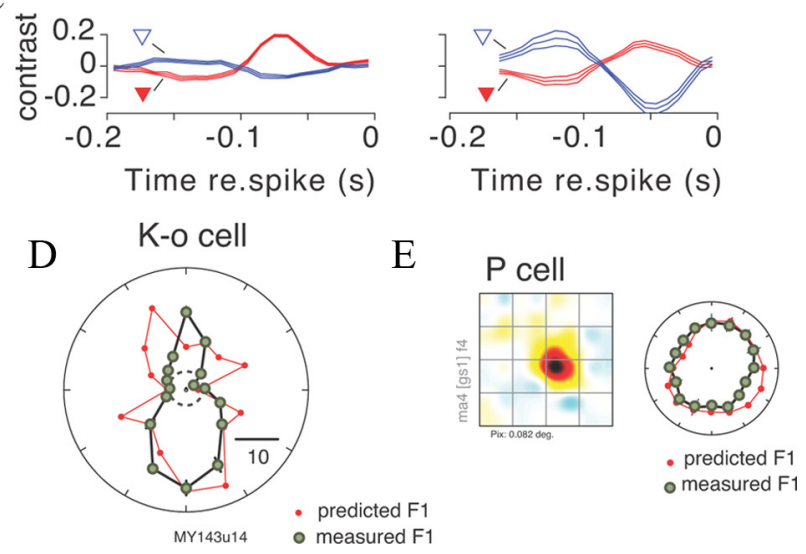

Figure 4. Linear prediction of orientation bias. A, Orientation selectivity (OSI) as a function of relative $S F$. Relative $S F$ was computed as the $S F$ at which direction tuning was measured, divided by the preferred SF for each receptive field. K-0 cells, $n=9 ; \mathrm{P}$ cells, $n=73 ; \mathrm{M}$ cells, $n=65$. The contour lines show the linear predictions of OSI when orientation tuning is computed for concentric center-surround receptive fields of varying center aspect ratio (major-to-minor axis ratio, indicated at the end of each contour line). $\boldsymbol{B}$, STA responses for achromatic white noise stimulus presented to two K-o cells. Grid bars indicate pixel borders. Pixel size (Pix:) is indicated below each graph. These $\mathrm{K}$-o receptive fields show spatially separated $0 \mathrm{n}$ - and Off-subregions. The "hand" and arrow symbols indicate these cells in $\boldsymbol{A}$. C, Temporal kernels for the pixels at the intersection of the border marks shown in $\boldsymbol{B}$. Error lines indicate SDs. $\boldsymbol{D}$, Linear prediction of direction tuning obtained by convolution of the STA with the direction tuning stimulus set. The tuning is consistent with the measured direction tuning (filled symbols). $\boldsymbol{E}$, Left, STA response for a P cell, shown at the same spatial scale as the K-o cell. Right, Measured and predicted direction tuning for this cell. Note that measured and predicted direction selectivity is low.

linear spatial summation for this K-o cell. Consistent data were obtained from the second cell tested (data not shown). As expected, the same procedure applied to responses of a $\mathrm{P}$ cell (Fig. 4E) predicts only low orientation selectivity. This example and the foregoing population analysis support the conclusion that the mechanism of orientation selectivity in K-o cells is distinct from the orientation bias 

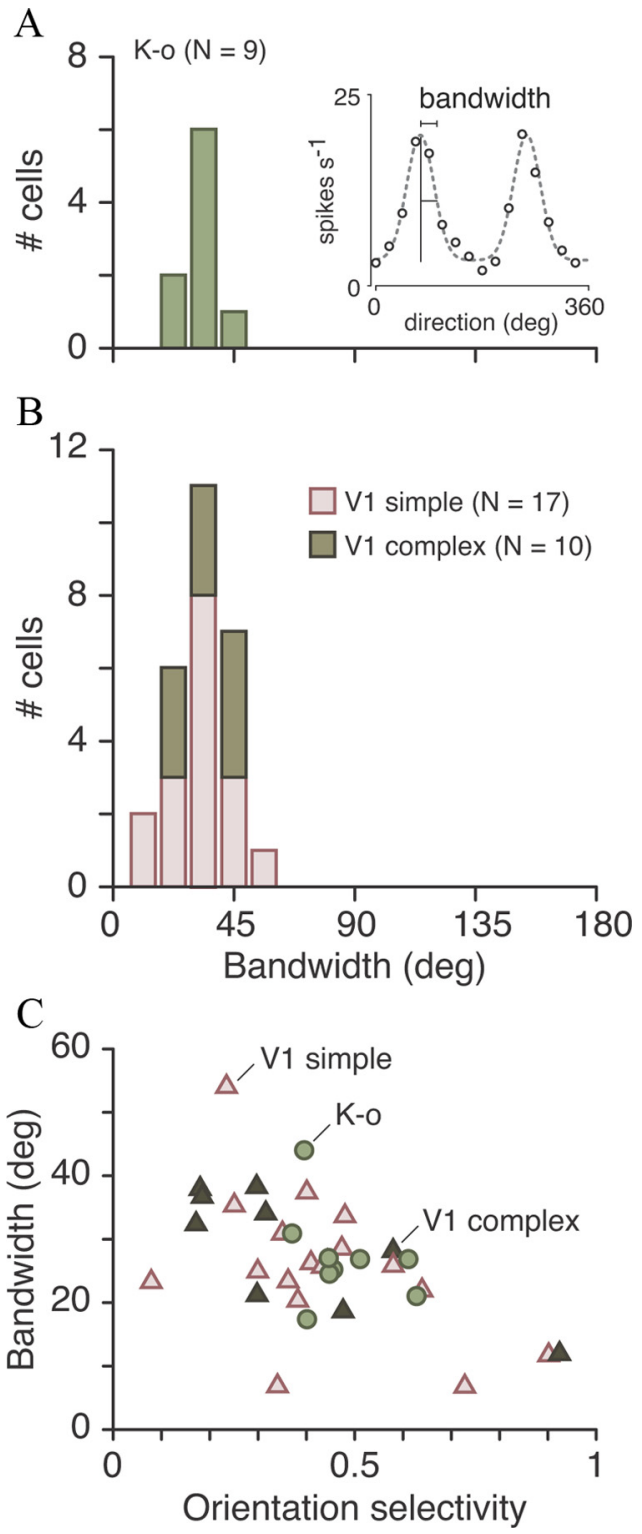

Figure 5. Orientation tuning bandwidth. $A$, Bandwidths (half-width at half-height) of K-0 cells calculated from a bimodal wrapped normal fit of direction tuning curves (inset graph). $\boldsymbol{B}$, Bandwidths of cortical (V1) cells. Note overlap of bandwidth with K-0 cells. C, Scatterplot showing bandwidth and orientation selectivity (OSI). Note that for both K-0 and V1 cells, tuning bandwidth sharpens as orientation selectivity increases, but narrow bandwidth is not essential for high orientation selectivity.

exhibited by $\mathrm{P}$ and $\mathrm{M}$ cells. We note that the On-Off subunit structure, combined with a temporal delay between subunits, could potentially explain the mild directional bias of K-o cells (Dawis et al., 1984; Tailby et al., 2010). For simplicity we did not explore this possibility further in the present study.

\section{Orientation bandwidth}

We next asked whether the strength of orientation tuning is comparable in $\mathrm{K}-\mathrm{o}$ and $\mathrm{V} 1$ cells, by measuring the orientation bandwidth (Fig. 5). Orientation tuning curves were fit with a bimodal wrapped normal function (Fig. $5 \mathrm{~A}$, inset). Mean bandwidth for K-o cells $\left(27.11^{\circ}\right.$, half-width at half-height, $\mathrm{SD} \pm 7.44, n=9$; Fig. $5 A)$ is comparable to V1 simple cells $(25.96 \pm 11.44, n=17$; Fig. $5 B)$ and V1 complex cells $(28.84 \pm 8.98, n=10$; Fig. $5 B)$. Orientation tuning curves of some V1 cells (chiefly cells showing pro-

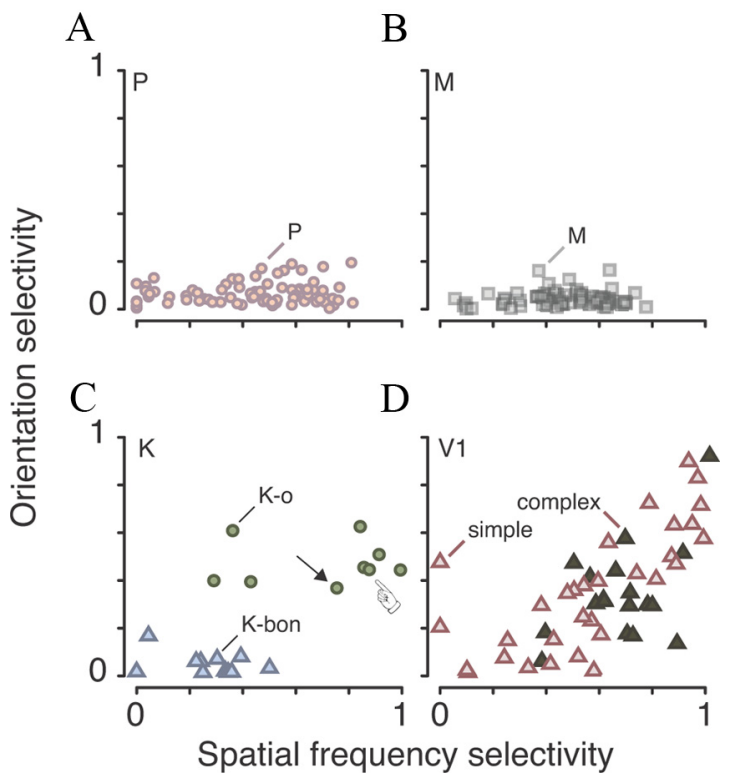

Figure 6. Orientation and SF selectivity. Scatterplots of orientation selectivity and SF selectivity. Increasing values indicate greater selectivity. $\boldsymbol{A}, \mathrm{P}$ cells $(n=79)$. $\boldsymbol{B}$, M cells $(n=65)$. C, K-o cells $(n=9)$ and K-bon cells ( $n=11)$. $\boldsymbol{D}$, Cortical (V1) cells: simple cells ( $n=31)$; complex cells $(n=18)$. Orientation selectivity for K-bon cells was calculated from S-cone-isolating gratings. Orientation selectivity for other cells was calculated from achromatic drifting gratings. The "hand" and arrow symbols indicate the cells shown in Fig. 4B-D.

nounced direction selectivity) were not well fit with the wrapped normal model. This stricture excluded 14 of 31 simple cells and 8 of 18 complex cells. With this limitation in mind it can be seen that there is heavy overlap of K-o and V1 populations where orientation selectivity (OSI) and bandwidth are compared as a scatterplot (Fig. 5C). We conclude from these data that $\mathrm{K}$-o cells in marmoset LGN show orientation selectivity comparable to that of orientation-tuned cells in marmoset V1.

\section{SF selectivity and receptive field size}

Further evidence that $\mathrm{K}$-o cells are distinct from $\mathrm{P}$ and $\mathrm{M}$ cells is the sharp SF tuning of K-o cells. SF selectivity was quantified by computing a spatial frequency selectivity index (SFI) from the DOG fits for each cell. A cell with SFI $=1$ shows completely bandpass tuning (no response at low SF); a cell with SFI $=0$ shows low-pass SF tuning. The mean SFI for K-o cells (0.70, SD \pm $0.27, n=9)$ was greater than the SFI for P cells $(0.43 \pm 0.24$, $n=79, p<0.02$, Wilcoxon rank-sum test), M cells $(0.46 \pm 0.17$, $n=65, p<0.02)$, or K-bon cells $(0.27 \pm 0.15, n=11, p<0.02)$ but comparable to V1 simple cells $(0.57 \pm 0.30, n=31, p=0.32)$ and V1 complex cells $(0.68 \pm 0.17, n=18, p=0.55)$. When orientation and SF selectivity are considered together, the K-o cell distribution overlaps with that of V1 cells (Fig. $6 A-D$ ). It should be noted, however, that the orientation selectivity in K-o cells appears uncorrelated to the SF selectivity, whereas there is clear correlation in the sample of V1 neurons.

Three K-o cells showed strong orientation selectivity and weaker SF selectivity (Fig. 5C), but were not obviously distinct from other K-o cells on other measured response parameters (Table 1). These data show that orientation selectivity in most $\mathrm{K}-\mathrm{o}$ cells is accompanied by bandpass SF tuning. We did not attempt to identify functional subgroups within K-o cells because the numbers are too low to yield interpretable data.

The K cell populations described so far in the literature tend to have larger receptive fields than do P and M cells (Irvin et al., 
Table 1. Summary of K-o cell tuning properties

\begin{tabular}{lrcccccc}
\hline ID & ECC & SIG & F1:F0 & P0 & OSI & DSI & SFI \\
\hline my136u9s0 & 3.25 & complex & 0.65 & 77.31 & 0.45 & 0.02 & 0.99 \\
my128u2s0 & 1.38 & complex & 0.68 & -44.24 & 0.46 & 0.02 & 0.86 \\
my115u9s0 & 16.50 & complex & 0.68 & 39.04 & 0.40 & 0.01 & 0.29 \\
my137u16s0 & 2.62 & complex & 0.89 & 29.12 & 0.51 & 0.01 & 0.91 \\
my134u13s0 & 4.43 & simple & 1.29 & -68.97 & 0.61 & 0.05 & 0.36 \\
my107u46s0 & 6.75 & simple & 1.57 & 76.38 & 0.63 & 0.05 & 0.84 \\
my071u11s0 & 7.70 & simple & 1.66 & 62.86 & 0.40 & 0.04 & 0.43 \\
my136u6s0 & 3.43 & simple & 1.94 & -76.88 & 0.45 & 0.11 & 0.88 \\
my143u14s0 & 1.44 & simple & 2.32 & -88.90 & 0.37 & 0.22 & 0.75
\end{tabular}

DSI, direction selectivity index; ECC, receptive field eccentricity (degrees); F1:F0 Fourier harmonic ratio; ID, cell identifier; SFI, spatial frequency selectivity index; OSI, orientation selectivity index; $\mathrm{PO}$, preferred orientation; SIG, simple/complex response signature.

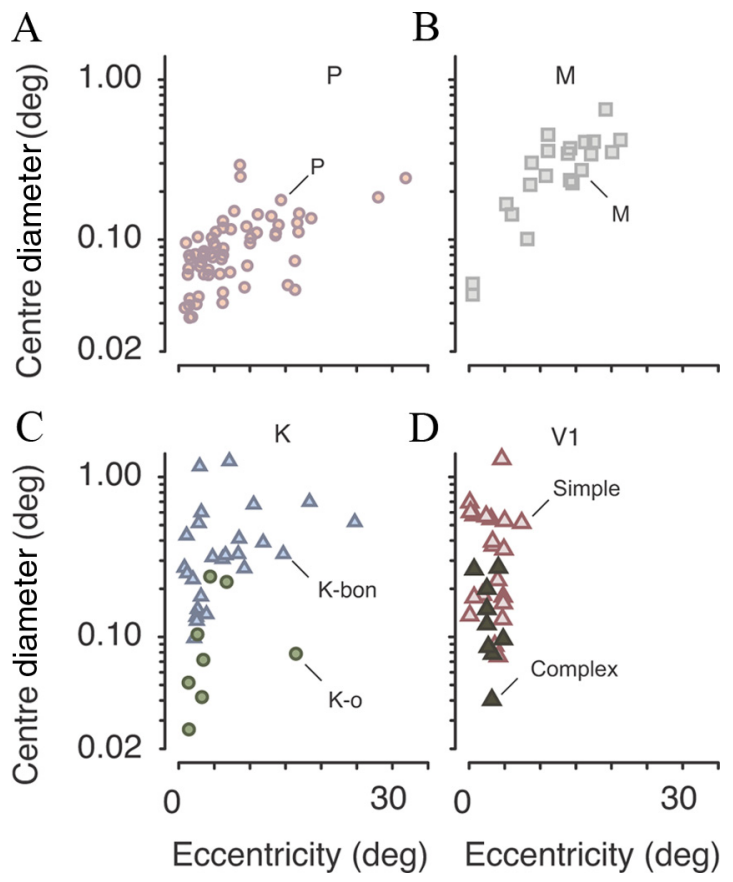

Figure 7. Receptive field center diameter of geniculate and cortical neurons. Receptive field center diameter was calculated as twice the DOG model fit radius. $\boldsymbol{A}$, P cells $(n=64)$. B, M cells $(n=21)$. C, K-o cells $(n=8)$ and K-bon cells $(n=25)$. D , Cortical (V1) cells: simple cells ( $n=$ $20)$; complex cells $(n=9)$. Note that receptive field size increases as a function of eccentricity for $P$ and $M$ cell cells. K-0 cells tend to have smaller center sizes than BON cells. V1 neurons have center sizes encompassing the range of LGN neurons. Recordings from V1 cells were limited to the central $10^{\circ}$.

1986, 1993; White et al., 2001; Xu et al., 2001, 2002; Solomon et al., 2002), and the dendritic fields of K-projecting ganglion cells are generally larger than the dendritic fields of $\mathrm{M}$ - and P-projecting cells (Rodieck and Watanabe, 1993; Dacey et al., 2003; Szmajda et al., 2008). We asked whether K-o cells have large receptive fields, allowing a small number of cells to encode a large area of visual space. This prediction was, however, not supported by the data. Figure 7 shows receptive field center diameter for LGN and V1 cells. As expected, receptive field diameter increases with eccentricity for $\mathrm{P}, \mathrm{M}$, and K-bon cells, and P cells show smallest center diameter at a given eccentricity (Derrington and Lennie, 1984; Crook et al., 1988; Usrey and Reid, 2000; Levitt et al., 2001; White et al., 2001; Solomon et al., 2002). Considering only cells with receptive fields in the first $10^{\circ}$ eccentricity, the receptive field sizes of K-o cells are significantly smaller than K-bon cells $(p<0.02)$, and close to that of P cells $(p=0.99)$ and $\mathrm{M}$ cells $(p=0.46)$. The receptive fields of K-o cells are likewise smaller than V1 simple cells $(p<0.02)$ and V1 complex cells $(p=0.07)$. It is important to note that (as shown in Fig. 4 ) the DOG model can provide only a rough description of the K-o cell receptive field. For simplicity in the present study we did not try to apply more complex receptive models (for example, we did not attempt to model the subunit structure implied by Fig. 4). Insofar as the DOG model does give an estimate of the spatial profile of the dominant subunit, we can nevertheless conclude that the receptive field dimensions of $\mathrm{K}$-o cells are not substantially different from the dimensions of $\mathrm{P}$ and $\mathrm{M}$ cells. The implications of this fact for the nature of inputs to K-o cells are taken up in the Discussion section.

\section{Contrast and TF tuning}

Contrast and TF tuning curves were analyzed to determine whether K-o cells showed other distinguishing characteristics from other LGN cells and/or similarities to V1 cells. Figure 8 shows contrast tuning for LGN and V1 cells. Raw tuning curves are shown in Figure $8 A-C$ and $G-I$. Averaged responses normalized to peak amplitude are shown in Figure $8 D-F$ and $J-L$. On average, $\mathrm{K}$-o cells, $\mathrm{P}$ cells, and $\mathrm{K}$-bon cells show linear contrast responses; $\mathrm{M}$ cells show saturating contrast responses; and V1 cells show mildly saturating responses (Derrington and Lennie, 1984; Kaplan and Shapley, 1986; Lee et al., 1990; Sclar et al., 1990; Solomon et al., 2002). Contrast tuning curves were fit with the Naka-Rushton model (see Materials and Methods) to calculate the contrast saturation constant, $c_{50}$. Low $\mathcal{c}_{50}$ values indicate high contrast gain and saturating responses. Contrast tuning curves with $c_{50}$ values of 1 or more are considered to be linear (we constrained the $c_{50}$ upper limit to two). The $c_{50}$ values for each group were as follows: K-o cells, $1.66 \pm 0.22$ (mean $\pm \mathrm{SEM}), n=7$; P cells, $1.27 \pm 0.06, n=129 ;$ M cells, $0.25 \pm 0.03, n=110$; K-bon cells, $1.37 \pm 0.15, n=21$; V1 simple cells, $0.95 \pm 0.18, n=21$; V1 complex cells, $0.77 \pm 0.16, n=21$. In summary, K-o cells have low contrast gain, comparable to $\mathrm{P}$ and $\mathrm{K}$-bon cells and lower than that of $\mathrm{M}$ cells. Figure 9 shows TF tuning for LGN and V1 cells. Raw tuning curves are shown in Figure $9 A-C$ and $G-I$. Normalized averaged curves are shown in Figure $9 D-F$ and $J-L$. The K-o cells preferred TF is close to $10 \mathrm{~Hz}(9.94 \pm 5.80 \mathrm{~Hz}$, mean $\pm \mathrm{SEM}, n=5)$. For comparison, $M$ cells show the highest preferred TF $(16.03 \pm 0.98 \mathrm{~Hz}, n=101)$ and lower TF is preferred by P cells $(7.58 \pm 0.32 \mathrm{~Hz}, n=116)$, K-bon cells (6.49 \pm 1.43, $n=18)$, V1 simple cells $(6.20 \pm 0.82, n=20)$, and V1 complex cells $(7.26 \pm 1.10, n=19)$. As evident from Figure 9, $\mathrm{K}-\mathrm{o}$ cells and K-bon cells tend to have low-pass TF profiles compared with the other cell groups studied. Temporal tuning of $\mathrm{P}$, $\mathrm{M}$, and K-bon populations are consistent with previous reports for diurnal monkeys (Derrington and Lennie, 1984; Lee et al., 1990; Solomon et al., 1999; Usrey and Reid, 2000; Levitt et al., 2001; Tailby et al., 2008a,b; Alitto et al., 2011). We quantified TF selectivity by a temporal frequency index (TFI): $1-\frac{r_{L}}{r_{P}}$, where $r_{L}$ is the response at $1 \mathrm{~Hz}$ and $r_{p}$ is the response at preferred frequency. A TFI value of 0 indicates low-pass temporal tuning; a TFI value of 1 indicates temporal bandpass tuning. The results show that K-o cells $(0.36 \pm 0.16$, mean \pm SEM, $n=5)$ and K-bon cells $(0.33 \pm 0.06, n=18)$ exhibit the most low-pass temporal tuning, and $\mathrm{M}$ cells and $\mathrm{V} 1$ simple cells exhibit the most bandpass tuning $(\mathrm{M}$, cells, $0.60 \pm 0.02, n=101 ; \mathrm{V} 1$ simple cells, $0.58 \pm$ $0.06, n=20)$. The remaining populations show intermediate TFI values ( $\mathrm{P}$ cells, $0.47 \pm 0.01, n=116$; V1 complex cells, $0.38 \pm$ $0.05, n=19)$. The observation that K-o cells show more low-pass temporal tuning than $\mathrm{P}$ or $\mathrm{M}$ cells $(p<0.05$, Wilcoxon rank-sum 

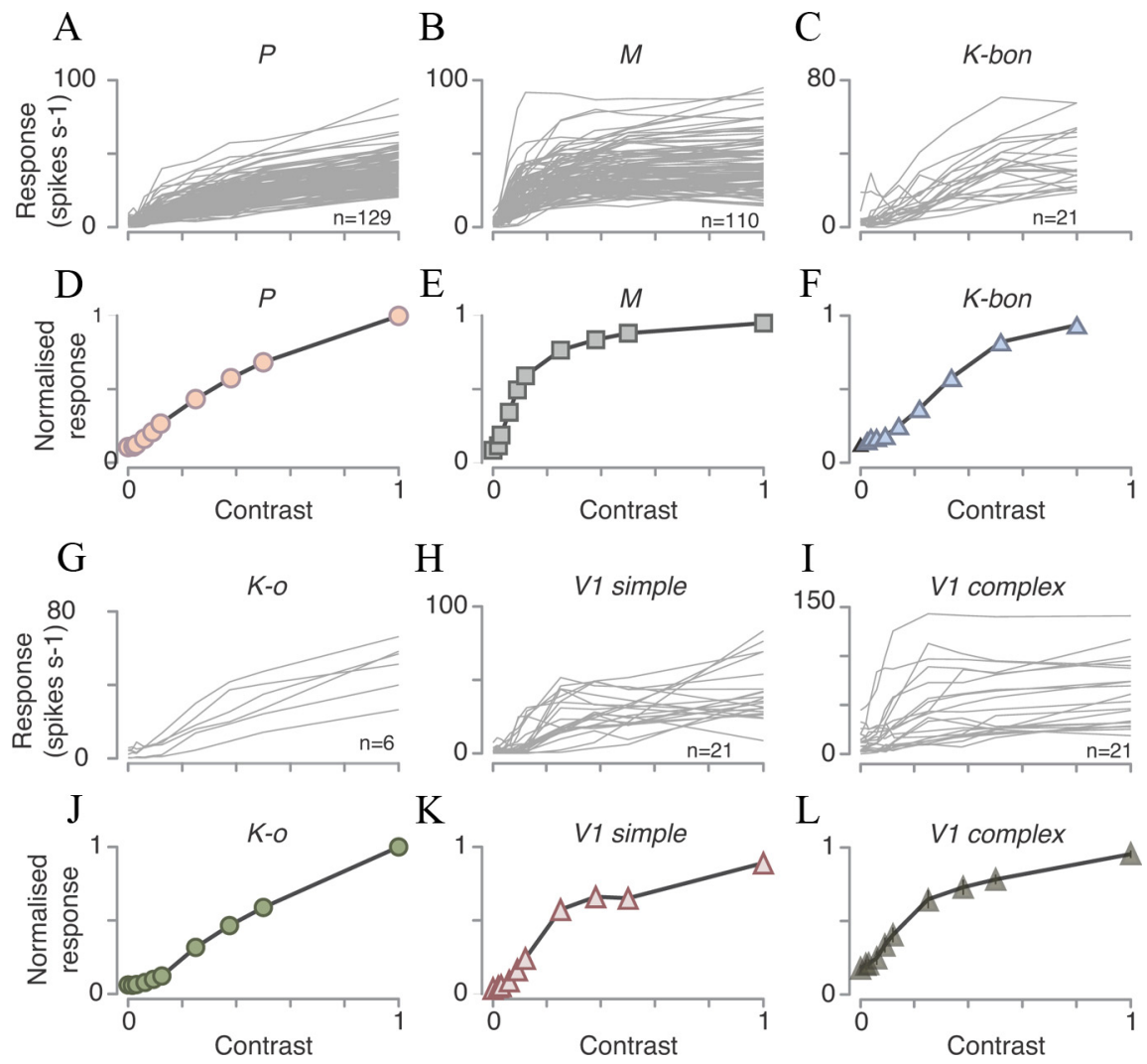

Figure 8. Contrast tuning curves of geniculate and cortical neurons. $A$, Individual tuning curves for $P$ cells. B, M cells. C, K-bon cells. $\boldsymbol{D}-\boldsymbol{F}$, Averaged normalized tuning curves for each class. The $P$ cells and $K$-bon cells show linear contrast tuning; $M$ cells show response saturation. $\mathbf{G}$, Individual tuning curves for K-0 cells. $\boldsymbol{H}$, Cortical (V1) simple cells. I, V1 complex cells. J-L, Averaged normalized tuning curves for each class. The K-0 cells show linear contrast tuning, V1 cells show saturating responses. Orientation selectivity for K-bon cells was calculated from S-cone-isolating gratings. Orientation selectivity for other cells was calculated from achromatic drifting gratings. Contrast is referred to maximum achievable with the monitor ( $80 \%$ for S-cone-isolating gratings, $>95 \%$ for achromatic gratings). Error bars indicate SEM. Many error bars are smaller than the data symbols.

test) is of interest, because it shows that simple convergence of $\mathrm{P}$ or $\mathrm{M}$ retinal afferents cannot explain the properties of K-o cells. We return to this point in a later section.

\section{S-cone input}

We show hereinafter that K-o cells are part of the koniocellular division of the LGN. The best-characterized division of the koniocellular pathway is the blue-On/yellow-Off (K-bon) pathway, comprising receptive fields that receive strong excitatory input from S-cones. We previously showed that some K-bon cells exhibit orientation and direction bias for achromatic gratings, as a result of spatial asymmetries of their cone inputs (Tailby et al., 2010). We therefore asked whether S-cone signals also influence $\mathrm{K}$-o cells. The relative weight of S-cone input was measured in six of nine K-o cells using achromatic and S-cone-isolating uniform fields, under square-wave temporal modulation at $0.5 \mathrm{~Hz}$. Five $\mathrm{K}$-o cells did not show any response to this stimulus. One K-o cell showed feeble responses; response of this cell to a drifting S-cone selective grating (presented at preferred achromatic orientation) was 15 spikes s $^{-1}$ at $80 \%$ S-cone contrast (SF 0.4 cycle per degree (CPD), TF $5 \mathrm{~Hz}$ ), cf. 43 spikes s $^{-1}$ at $50 \%$ achromatic contrast (SF $0.8 \mathrm{CPD}$, TF $5 \mathrm{~Hz}$ ). These data suggest that $\mathrm{S}$-cone signals do not have a strong influence on $\mathrm{K}$-o receptive fields. Previous studies show that $\mathrm{P}$ and $\mathrm{M}$ cells are functionally isolated from S-cone input, that is, the strength of $\mathrm{S}$-cone signals to $\mathrm{P}$ and $\mathrm{M}$ cells is below that expected on the basis of random cone connections (Sun et al., 2006; Tailby et al., 2008b). Our sample of K-o cell is too small to answer the question of whether K-o cells are also isolated from $\mathrm{S}$-cone signals in this way, but do rule out a prominent $\mathrm{S}$-cone input to $\mathrm{K}$-o cells as shown for K-bon and K blue-Off cells.

\section{Binocular responses}

Where tested ( $n=4)$, K-o cells showed an increase in discharge evoked through monocular stimulation of either eye. For expediency we characterized K-o cells by measuring responses to monocular stimulation through the dominant eye. In two instances the cell recording was held for long enough to allow properties of nondominant eye inputs to be explored. Figure $10, A-F$, shows the response of one K-o cell to stimuli delivered sequentially through each eye. The contralateral (right) eye was dominant (Fig. 10A-C). Stimulation through the ipsilateral eye (Fig. 10D-F) also produced robust responses at the grating modulation frequency, at approximately one-third the amplitude of responses evoked though the contralateral eye (Fig. 10, compare $A, D$ ). Identical spike waveforms consistent with soma recordings (Bishop et al., 1962) were recorded for stimulation through either eye (Fig. 10A, D, insets). This observation rules out the possibility that the recordings come from two different cells. This $\mathrm{K}$-o cell was recorded in the $\mathrm{KC}$ layer between the contralateral and ipsilateral $\mathrm{P}$ layers (the reconstructed position of this cell is indicated in Fig. 13), allowing the possibility for convergent inputs from both eyes. Interestingly, the two eyes appear to generate different orientation preference (Fig. $10 A, D$ ). In paralyzed marmosets the left and right eye optical axes can be separated by up to $4^{\circ}$ horizontally and up to $2^{\circ}$ vertically (P. Martin, S. Solomon, unpublished observations). We did not attempt to control for the resulting differential image rotation, as any discrepancy would be smaller than the orientation sampling increment $\left(22.5^{\circ}\right)$. Figure $10, G-I$, shows another example of binocular input to a $\mathrm{K}$-o cell. The dominant eye was the ipsilateral (right) eye. This cell showed only feeble responses to gratings presented through the contralateral eye. However, responses to brief ( $200 \mathrm{~ms}$ ), uniform stimuli ( $12^{\circ}$ diameter, $60 \%$ contrast) showed binocular facilitation (Fig. 10I); maximum response to ipsilateral stimulation was 30 spikes s ${ }^{-1}$; to contralateral stimulation 25 spikes s$^{-1}$; and to binocular stimulation 80 spikes $\mathrm{s}^{-1}$ (Fig. 10G-I). Spike waveforms (Fig. 10G-I, insets) recorded under ipsilateral or contralateral eye stimulation are indistinguishable, and are consistent with soma recording. These limited data suggest that K-o cell responses can be influenced (either directly or indirectly) by inputs from both eyes.

\section{Objective classification of K-o cells}

In this section we support our classification of K-o cells as a distinct functional population in the LGN, by showing that their responses can be objectively distinguished from those of other LGN cells. Objective classification was performed using multivariate dimension reduction (principal component analysis and 
objective partitioning ( $k$-means clustering) as described (see Materials and Methods). Figure $11 \mathrm{~A}$ shows the LGN populations projected onto first and second principal component weights derived from the following receptive field properties: TF selectivity (TFI), SF selectivity (SFI), orientation selectivity (OSI), achromatic contrast sensitivity $\left(c_{50}\right)$, and receptive field center radius $\left(R_{c}\right)$. Here, as expected (Irvin et al., 1986; White et al., 2001), the P, M, and K-bon cells form partially overlapping clusters. Five K-o cells had measures for all the input parameters; these cells form a distinct cluster that appears well separated from the other LGN populations (Fig. 11A). Projections of the input parameters onto the reduced data space (Fig. 11B) shows that orientation and SF selectivity are the main drivers of variance between $\mathrm{K}$-o cells and the other LGN populations.

We next asked whether unsupervised $(k$-mean) partitioning can support our cell classifications. Data were partitioned into four clusters; the centroid positions of these clusters (Fig. 11B, target symbols) correspond approximately to the four LGN cell classes. Cluster 4 is exclusively occupied by K-o cells. Clusters 1-3 are constituted of mixtures of the other LGN cell classes, with largest contribution from $\mathrm{P}$ cells (cluster 1), $\mathrm{M}$ cells (cluster2), or $\mathrm{K}$-bon cells (cluster 3 ). This result shows that the K-bon cells can be objectively classified by their response properties, supporting their existence as a distinct functional class in marmoset LGN.

\section{Cell location}

Locations of four K-o cells were directly identified from brain reconstructions in three animals. Figure 12 shows an example of Nissl staining (Fig. 12A) and unstained autofluorescence (Fig. $12 B$ ) in sections containing two recording tracks. Reconstruction of recorded cells on one these tracks is shown in Figure 12C. One $\mathrm{K}-\mathrm{o}$ cell was encountered on this track; the position was reconstructed in the internal M layer near layer K2 (Fig. 12C, arrow). A second example track (Fig. 12D) shows recording locations of two K-o cells between the internal and external P layers in layer $\mathrm{K} 4$. A fourth K-o cell (data not shown) was reconstructed in layer $\mathrm{K} 3$ between the $\mathrm{P}$ and $\mathrm{M}$ layers (my71u11). Locations of four additional K-o cells were inferred from eye dominance transitions and functional properties of neighboring neurons in the track. The recording locations of these and the reconstructed K-o cells are summarized in Figure 13. In sum, six of eight K-o cells were assigned to $\mathrm{K}$ layers, with two cells assigned to $\mathrm{M}$ layers. These data constitute our evidence that orientation-selective receptive fields are segregated to the K visual pathways.

\section{Discussion}

Orientation-selective receptive fields comparable to the K-o cells described here have not, to our knowledge, been reported in LGN of any mammal studied so far. In the following we first ask
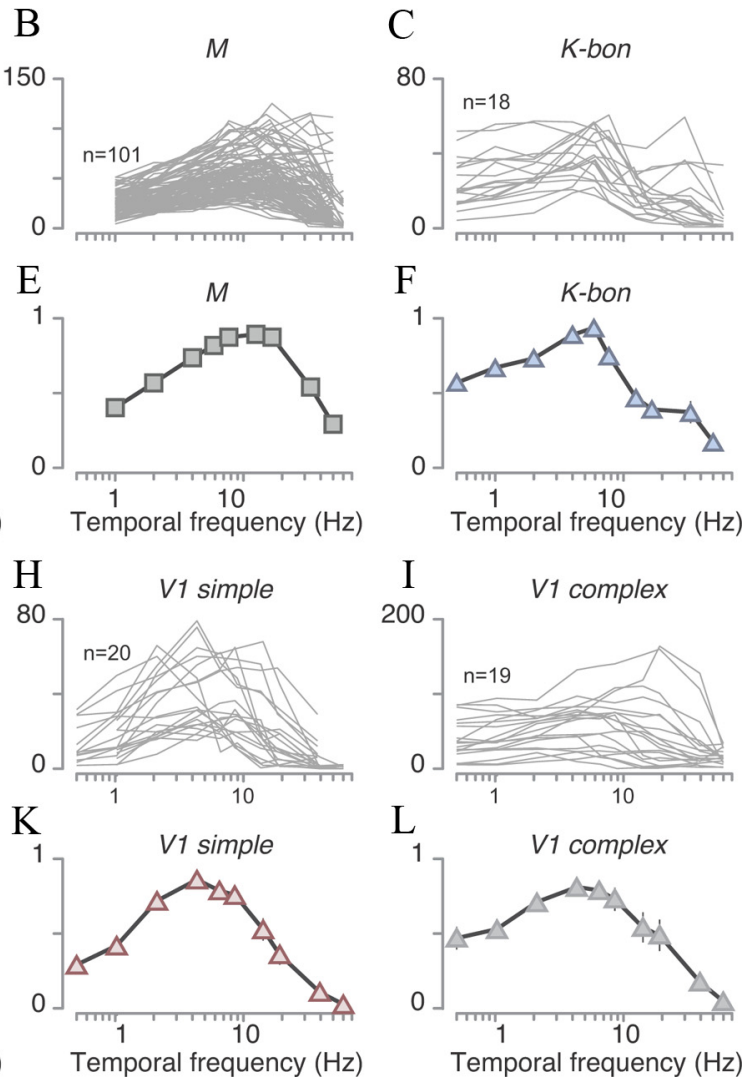

Figure 9. TF tuning curves of $L G N$ and V1 cells. $\boldsymbol{A}$, Individual tuning curves for P cells. $\boldsymbol{B}, \mathrm{M}$ cells. $\boldsymbol{C}$, K-bon cells. $\boldsymbol{D}-\boldsymbol{F}$, Averaged normalized tuning curves for each class. $\mathbf{G}$, Individual tuning curves for K-o cells. $\boldsymbol{H}$, Cortical (V1) simple cells. I, V1 complex cells. $J-L$, Averaged normalized tuning curves for each class. The M cells show the highest preferred TF, $16.03 \pm 0.98 \mathrm{~Hz}$ (mean \pm SEM); , $7.58 \pm 0.32$; K-bon cells, $6.49 \pm 1.43 ; \mathrm{K}-0$ cells $9.28 \pm 4.28$; V1 simple cells, $6.20 \pm 0.82$; V1 complex cells, $7.26 \pm 1.10$ V1 simple cells, $0.58 \pm 0.06$; V1 complex cells, $0.38 \pm 0.05$. Tuning curves for K-bon cells were calculated from S-coneisolating gratings. Orientation selectivity for other cells was calculated from achromatic drifting gratings. Error bars indicate SEM. Many error bars are smaller than the data symbols.

whether K-o cells represent a new functional population of LGN cells. Second we address possible sources of orientation selectivity in subcortical receptive fields. Finally we speculate on possible functional roles for orientation signals in the LGN.

\section{Do K-o cells represent a new functional population of LGN cells?}

The K-o cells were very rarely encountered, inviting the obvious objection that their responses arise from spurious recordings, or are a statistical anomaly without relevance for visual processing. The first possibility is easy to dismiss. The $\mathrm{K}$-o receptive fields are not, for example, recordings from two neurons with spatially offset receptive fields. Spike waveforms of all K-o cells showed consistent homogeneous shape expected from single cell soma recordings (Fig. $10 B, E, G-I$ ), and none of the K-o spike trains recorded showed refractory period violations $(>1$ spike in $<2$ ms, data not shown). The unlikely possibility that two neurons with identical spike waveforms were recorded simultaneously can likewise be dismissed, because in this case gratings drifting orthogonal to the preferred direction would elicit robust responses. Responses of K-o cells to nonpreferred orientations, however, fall to (or below) the maintained discharge rate (Figs. 1, 10).

The question whether the low encounter rate of K-o cells reflects a vanishingly low frequency of these cells in LGN is not 
A
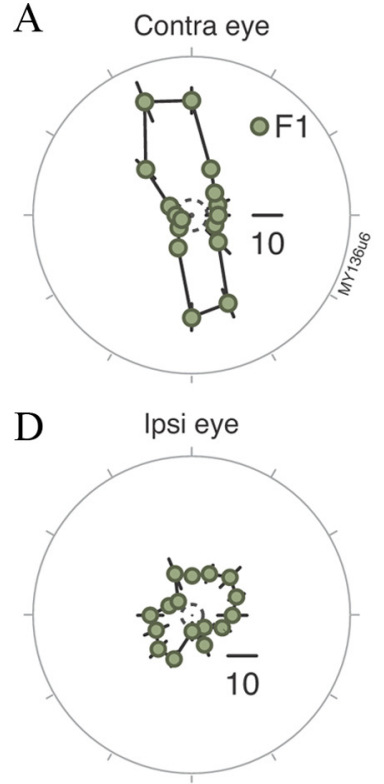

G

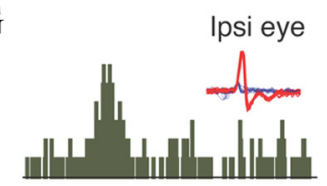

$\mathrm{H}$

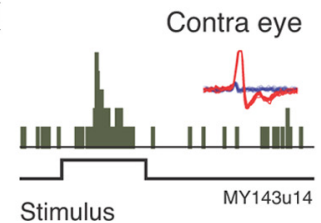

B

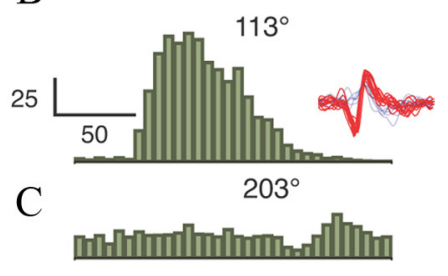

E

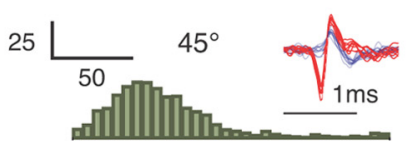

$\mathrm{F}$

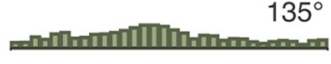

I

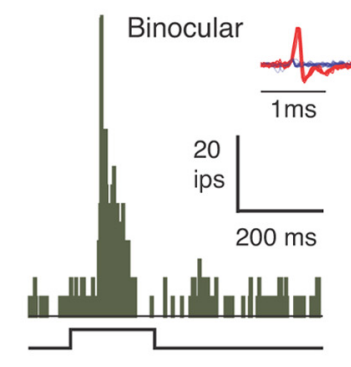

Figure 10. Binocular input to K-o cells. A, Orientation tuning curve of a K-o cell for gratings presented to the contralateral (right) eye. Dashed line shows amplitude of maintained activity. Error bars indicate SEM. $\boldsymbol{B}$, PSTH for preferred orientation. Inset shows example spike waveforms. C, PSTH for orthogonal-to-preferred grating. $\boldsymbol{D}-\boldsymbol{F}$, Show responses in the same format, for gratings presented through the ipsilateral (left) eye. Note that the spike waveforms in $\boldsymbol{B}$ and $\boldsymbol{E}$ are indistinguishable, indicating recording from the same neuron. The orientation selectivity (OSI) for contralateral eye stimulation was 0.45 ; OSI for ipsilateral eye stimulation was 0.17 . Stimulus parameters were as follows: contrast 1, SF $1.5 \mathrm{cyc} \mathrm{deg}^{-1}$, TF $5 \mathrm{~Hz}$, stimulus diameter $5^{\circ}$. G-I, Example of binocular facilitation in a second K-o cell. PSTHs show response to a brief $(200 \mathrm{~ms})$, white circular uniform stimulus $\left(\right.$ size $\left.12^{\circ}\right)$. Stimulus duration is represented by the trace below each histogram. Response to stimulation through both eyes (binoc) is greater than response to stimulation through the ipsilateral eye alone (ipsi) or contralateral eye alone (contra). Scale bar: (in $I$ ) G-I, $1 \mathrm{~ms}$.

simple to answer. The K pathway cells in primate LGN are small and difficult to record (Norton and Casagrande, 1982; Irvin et al., 1986; Solomon et al., 2006; Tailby et al., 2007). We preferentially recorded from $\mathrm{K}$ layers using high impedance ( $>10 \mathrm{MOhm}$ ) electrodes. Such electrodes give good isolation of extracellular action potentials from small cell bodies, at the cost of low encounter rates. Another problem we encountered is that the K-o cells showed low maintained discharge, and could not be easily targeted with visual "lure" stimuli. In contrast, P and M cells respond vigorously to achromatic gratings of any orientation; $\mathrm{K}$-bon cells respond vigorously to S-cone selective gratings; and vigorous maintained activity in koniocellular suppressed-bycontrast cells is quenched by flashed or moving stimuli. These response signatures are obvious to a trained observer. In other words, at least three factors (electrode bias, low maintained discharge rate, and high stimulus selectivity) would serve to reduce the encounter rate of K-o cells relative to other LGN receptive
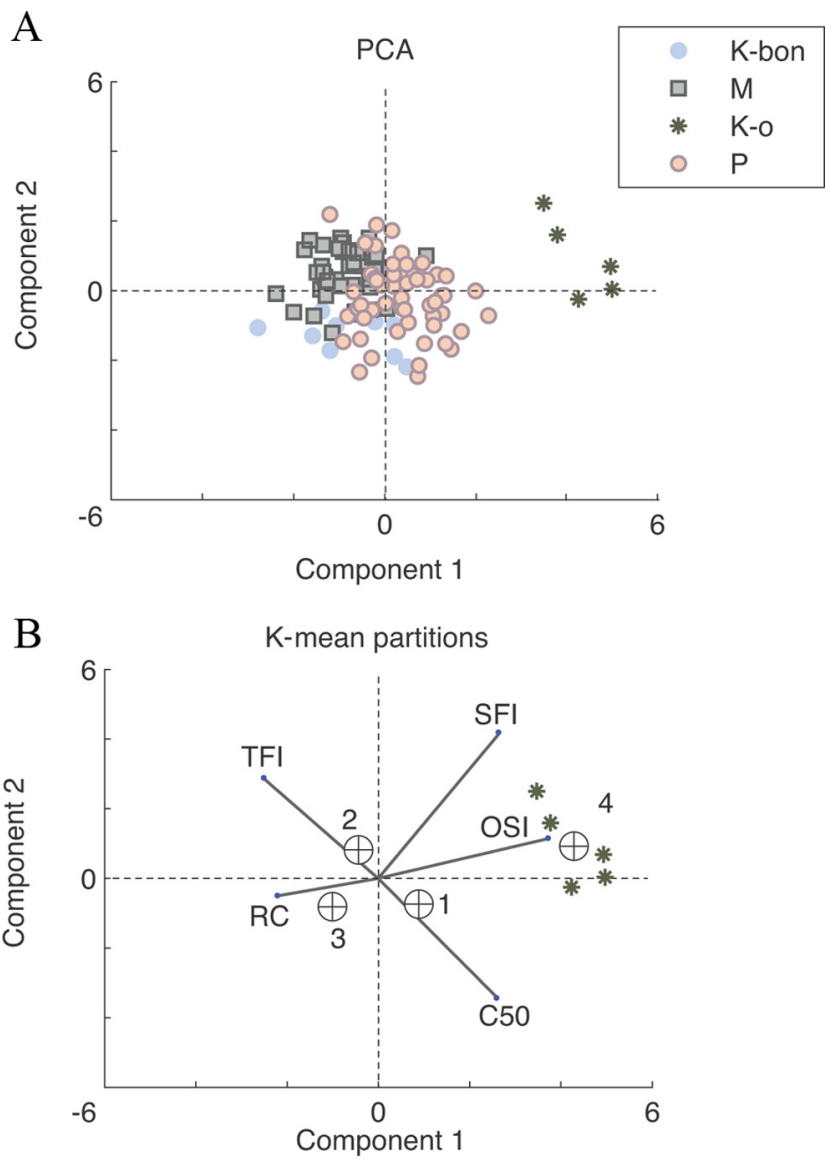

Figure 11. Objective classification of K-o cells. A, B, Principal component analysis and objective clustering. The scatterplot shows first and second principal components derived from the following receptive field metrics, as described in the text: TFI, SFI, OSI, contrast sensitivity (half-saturation constant, $(50)$, receptive field center radius ( $\mathrm{RC}$ ). The distribution of cell populations on these metrics is show in $\boldsymbol{A}$. The vector projection of each metric on the principal component plane is shown in $\boldsymbol{B}$. Note that $\mathrm{K}$ - 0 cells form a distinct cluster; the other cell groups ( $K$-bon, M, P) form partially overlapping clusters. The "target" symbols in $\boldsymbol{B}$ show the centroid positions of four clusters in this dataset derived from $k$-means clustering. The centroid of cluster four corresponds to the position of K-o cells.

fields. On the other hand, the $\mathrm{K}$-o receptive fields are as small as $\mathrm{P}$ and $\mathrm{M}$ cell fields (Fig. 7A-C): this fact makes it difficult to conceive that K-o cells could uniformly tile the visual field at multiple orientations. We return to these questions in a later section, for now it is important to reiterate that the K-o cells form a group that can be can be objectively distinguished from $\mathrm{P}$ and $\mathrm{M}$ cells (Fig. 11). All these observations suggest that the K-o cells form a distinct and previously uncharacterized receptive field type in the monkey LGN.

\section{Where does orientation selectivity arise?}

The strongest source of synaptic drive to the LGN is the retina, and the visually driven spike rates exhibited by K-o cells are consistent with direct retinal drive (Figs. 1, 4, 8-10). A distinct class of ganglion cell selective for vertical orientations was reported (Levick, 1967), and has recently been thoroughly characterized (Venkataramani and Taylor, 2010), in rabbit retina. These cells are functionally (He et al., 1998) and morphologically (Venkataramani and Taylor, 2010) distinct from directionselective ganglion cells, and are also distinct from a class of ganglion cells selective for horizontal orientations (Levick, 1967; Venkataramani and Taylor, 2010). A class of ganglion cells pre- 

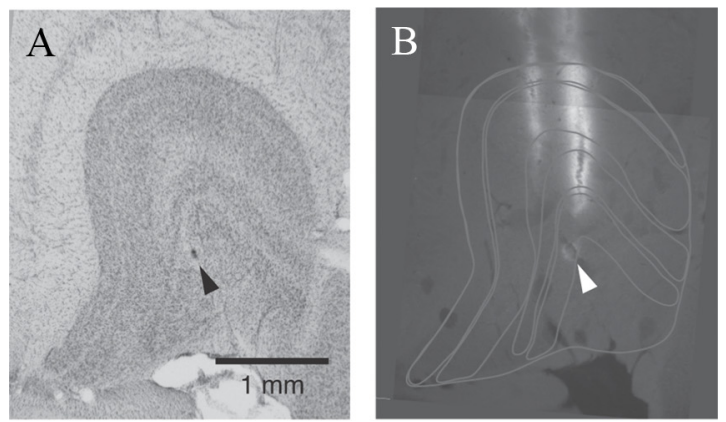

$\mathrm{C}$
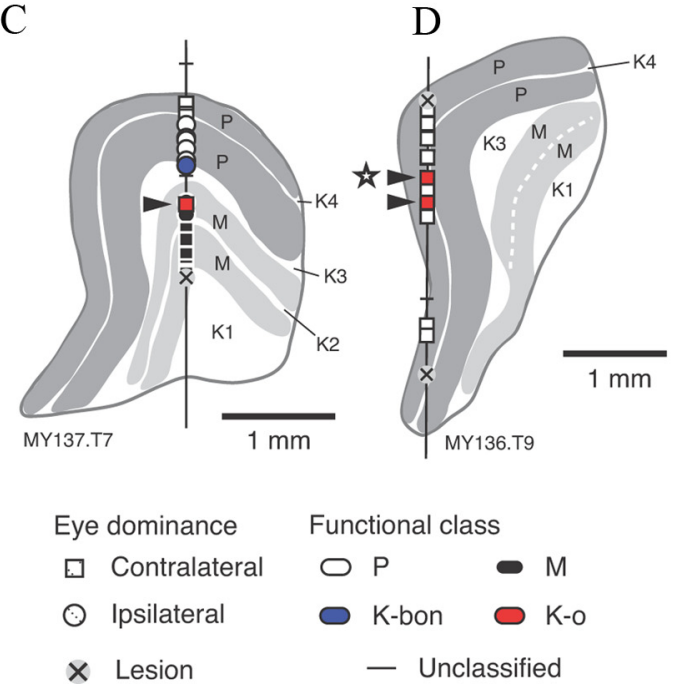

Figure 12. Electrode track reconstruction of K-o cells. $A$, Micrograph of a coronal section stained for Nissl substance to reveal the cell layers of the LGN. $\boldsymbol{B}$, Micrograph of the neighboring section showing electrode track revealed by autofluorescence. Arrowhead indicates an electrolytic lesion ( $+5 \mu \mathrm{A}, 5 \mathrm{~s}$ ). Autofluorescent tracks and lesions, together with changes in eye dominance and functional cell properties, were used to align the micrographs with the microdrive depths of recorded cells. C, Schematic representations of these sections showing geniculate layers, electrode track, and recorded cells. K-o cells are indicated by red symbols and arrowheads. The star in $\boldsymbol{D}$ indicates the $\mathrm{K}-\mathrm{o}$ cell described in Figure $10 \mathrm{~A}-\mathrm{C}$.

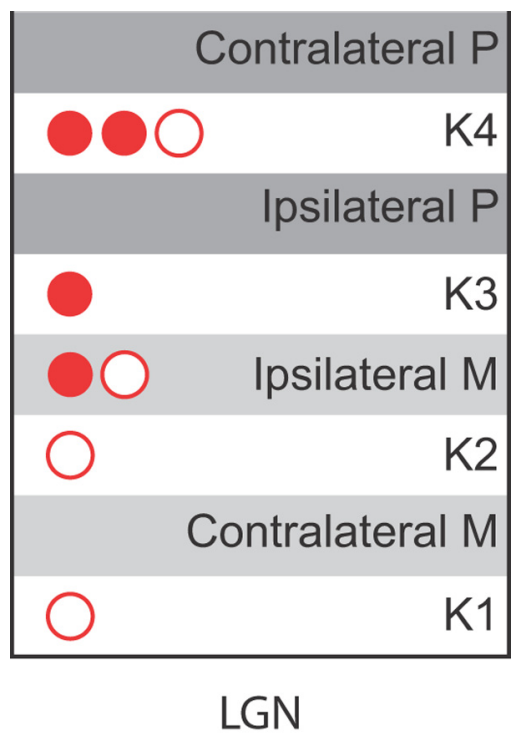

Figure 13. Summary of K-o cell recording positions. Closed symbols represent cells whose recording positions were anatomically reconstructed. Open symbols represent cells whose positions were inferred from physiological measures. ferring upward image motion (Kim et al., 2008) is present in mouse retina but, in contrast to these and other directionselective cells (for review, see Vaney et al., 2012), the K-o cells show only weak direction selectivity.

The K-o cells show some functional overlap with $\mathrm{P}$ cells on three measures (receptive field size, Fig. 7; contrast sensitivity, Fig. 8; temporal sensitivity, Fig. 9). As explained above, convergence of two vertically aligned $\mathrm{P}$ afferents with the same response polarity cannot account for the selectivity of K-o cells. Such convergence would not explain the feeble responses of K-o cells to low spatial frequencies, nor how the complex-like property of some K-o cells could arise. Further, K-o cell temporal tuning has more low-pass characteristic than that of P cells (Fig. 9); this difference is hard to explain by a simple phase-invariant addition of responses. Finally, reverse correlation maps from two K-o cells (Fig. 4C) showed elongated, spatially segregated On- and Offsubfields, consistent with the idea that orientation selectivity in $\mathrm{K}-\mathrm{o}$ cells is based on convergence of On- and Off-pathways, as considered important for cortical orientation selectivity (Heggelund and Moors, 1983; Alonso et al., 1996; Jin et al., 2011).

In addition to the retina, potential sources of orientationtuned inputs to LGN are the superior colliculus and parabigeminal nucleus. These projections specifically target the $\mathrm{K}$ layers (Harting et al., 1978, 1986, 1991). Neurons in the mouse superior colliculus commonly exhibit orientation-selective receptive fields (Wang et al., 2006), but there is less evidence for orientation tuning in macaque monkey colliculus or in the colliculoparabigeminal projection (Schiller and Koerner, 1971; Cynader and Berman, 1972; Marrocco et al., 1981). In our recent study of marmoset superior colliculus (Tailby et al., 2012) we found only $3 / 29$ tested neurons that showed orientation selectivity (OSI) $>$ 0.3 . Therefore the orientation selectivity of $\mathrm{K}$-o cells is unlikely to originate in the superior colliculus.

A third possible source of orientation-tuned inputs to LGN is feedback projection from V1. The K-o cells do share similarities to cortical neurons and show overlap on spatial tuning and orientation bandwidth (Figs. 5, 6). Cortical feedback does influence orientation tuning in the LGN (Vidyasagar and Urbas, 1982; Sillito et al., 1993; Wang et al., 2006) and plays a role in binocular interactions of LGN neurons (Schmielau and Singer, 1977). Cortical inputs, however, are considered to modulate LGN relay cell excitability rather than driving neuronal depolarization as strongly as retinal inputs do (Sincich et al., 2007). In sum, the most likely source of driving input to K-o cells is from verticallyselective retinal ganglion cells, or from convergence in the LGN.

\section{Relevance for visual processing}

What relevance could K-o cells have for visual perception? As outlined above, the extreme argument that all cortical orientation selectivity is inherited from K-o cells can be ruled out, because there are simply not enough cells in the entire LGN to achieve a complete high-resolution map of all orientations. One alternate possibility is that subcortical orientation signals could "seed" the production of cortical orientation domains during development (Vidyasagar et al., 1996; Jin et al., 2011; cf. Paik and Ringach, 2012).

Some K cells make direct projections to the middle temporal (MT) area bypassing V1 (Benevento and Yoshida, 1981; Yukie and Iwai, 1981; Sincich et al., 2004; Warner et al., 2010). It is possible that $\mathrm{K}$-o cells are included in this projection, but the weak direction selectivity in K-o cells stands in sharp contrast to the high selectivity of most MT cells for image drift direction. Relatedly, direction-selective cells form the main input to the 
accessory optic system for retinal image stabilization and ocular motor control (for review, see Simpson, 1984). The lack of direction selectivity in K-o cells means that they cannot be an aberrant projection of some axons from these eye-movement control circuits.

The small receptive field size of $\mathrm{K}$-o cells (Fig. 7C), and the low overall proportion of $\mathrm{K}$ pathway cells suggest that K-o cells must sample the visual field sparsely and/or for a limited range of orientations. On this line of reasoning, any relevance of $\mathrm{K}$-o cells for visual processing should be linked to their selectivity for orientations close to vertical (Figs. 1, 2, 4). These observations lead to the speculation that K-o cells could contribute to a primitive system for binocular processing, either directly or by feeding onto binocular neurons at a later processing stage. The limited data on binocular responses in K-o cells (Fig. 10) suggest that K-o cell binocular responses are unlike those of binocular cells in V1, which show well matched orientation preferences in the two eyes. We do not yet have sufficient data on binocular inputs to K-o cells to draw firmer conclusions. Regardless of these unanswered questions, the presence of cortical-like orientation selectivity in LGN gives further evidence that analysis of complex image features does not occur exclusively in visual cortex in primates.

\section{Note}

Note added in proof. Piscopo et al. (2013) recently reported orientationselective fields in mouse LGN.

\section{References}

Alitto HJ, Moore BD 4th, Rathbun DL, Usrey WM (2011) A comparison of visual responses in the lateral geniculate nucleus of alert and anaesthetized macaque monkeys. J Physiol 589:87-99. CrossRef Medline

Alonso JM, Usrey WM, Reid RC (1996) Precisely correlated firing in cells of the lateral geniculate nucleus. Nature 383:815-819. CrossRef Medline

Benevento LA, Yoshida K (1981) The afferent and efferent organization of the lateral geniculo-prestriate pathways in the macaque monkey. J Comp Neurol 203:455-474. CrossRef Medline

Berens P (2009) CircStat: a MATLAB toolbox for circular statistics. J Stat Software 31.

Bishop PO, Burke W, Davis R (1962) The interpretation of the extracellular response of lateral geniculate cells. J Physiol 162:451-472. Medline

Buzás P, Blessing EM, Szmajda BA, Martin PR (2006) Specificity of M and L cone inputs to receptive fields in the parvocellular pathway: random wiring with functional bias. J Neurosci 26:11148-11161. CrossRef Medline

Casagrande VA (1994) A third parallel visual pathway to primate area V1. Trends Neurosci 17:305-310. CrossRef Medline

Chapman B, Zahs KR, Stryker MP (1991) Relation of cortical cell orientation selectivity to alignment of receptive fields of the geniculocortical afferents that arborize within a single orientation column in ferret visual cortex. J Neurosci 11:1347-1358. Medline

Chichilnisky EJ (2001) A simple white noise analysis of neuronal light responses. Network 12:199-213. CrossRef Medline

Croner LJ, Kaplan E (1995) Receptive fields of P and M ganglion cells across the primate retina. Vision Res 35:7-24. CrossRef Medline

Crook JM, Lange-Malecki B, Lee BB, Valberg A (1988) Visual resolution of macaque retinal ganglion cells. J Physiol 396:205-224. Medline

Cynader M, Berman N (1972) Receptive-field organization of monkey superior colliculus. J Neurophysiol 35:187-201. Medline

Dacey DM, Peterson BB, Robinson FR, Gamlin PD (2003) Fireworks in the primate retina: in vitro photodynamics reveals diverse LGN-projecting ganglion cell types. Neuron 37:15-27. CrossRef Medline

Dakin SC, Mareschal I, Bex PJ (2005) Local and global limitations on direction integration assessed using equivalent noise analysis. Vision Res 45: 3027-3049. CrossRef Medline

Dawis S, Shapley R, Kaplan E, Tranchina D (1984) The receptive field organization of X-cells in the cat: spatiotemporal coupling and asymmetry. Vision Res 24:549-564. CrossRef Medline

Derrington AM, Lennie P (1984) Spatial and temporal contrast sensitivities of neurones in lateral geniculate nucleus of macaque. J Physiol 357:219240. Medline
De Valois RL, Yund EW, Hepler N (1982) The orientation and direction selectivity of cells in macaque visual cortex. Vision Res 22:531-544. CrossRef Medline

Enroth-Cugell C, Robson JG (1966) The contrast sensitivity of retinal ganglion cells of the cat. J Physiol 187:517-552. Medline

Fitzpatrick D, Itoh K, Diamond IT (1983) The laminar organization of the lateral geniculate body and the striate cortex in the squirrel monkey (Saimiri sciureus). J Neurosci 3:673-702. Medline

Forte JD, Hashemi-Nezhad M, Dobbie WJ, Dreher B, Martin PR (2005) Spatial coding and response redundancy in parallel visual pathways of the marmoset Callithrix jacchus. Vis Neurosci 22:479-491. Medline

Harting JK, Casagrande VA, Weber JT (1978) The projection of the primate superior colliculus upon the dorsal lateral geniculate nucleus: autoradiographic demonstration of interlaminar distribution of tectogeniculate axons. Brain Res 150:593-599. CrossRef Medline

Harting JK, Hashikawa T, Van Lieshout D (1986) Laminar distribution of tectal, parabigeminal and pretectal inputs to the primate dorsal lateral geniculate nucleus: connectional studies in Galago crassicaudatus. Brain Res 366:358-363. CrossRef Medline

Harting JK, Van Lieshout DP, Hashikawa T, Weber JT (1991) The parabigeminogeniculate projection: connectional studies in eight mammals. J Comp Neurol 305:559-581. CrossRef Medline

Hashemi-Nezhad M, Blessing EM, Dreher B, Martin PR (2008) Segregation of short-wavelength-sensitive ("blue") cone signals among neurons in the lateral geniculate nucleus and striate cortex of marmosets. Vision Res 48:2604-2614. CrossRef Medline

He SG, Levick WR, Vaney DI (1998) Distinguishing direction selectivity from orientation selectivity in the rabbit retina. Visual Neurosci 15:439447.

Heggelund P, Moors J (1983) Orientation selectivity and the spatial distribution of enhancement and suppression in receptive fields of cat striate cortex cells. Exp Brain Res 52:235-247. Medline

Henry GH, Bishop PO, Dreher B (1974) Orientation, axis and direction as stimulus parameters for striate cells. Vision Res 14:767-777. CrossRef Medline

Hicks TP, Lee BB, Vidyasagar TR (1983) The responses of cells in macaque lateral geniculate nucleus to sinusoidal gratings. J Physiol 337:183-200. Medline

Hubel DH, Wiesel TN (1977) Ferrier lecture. Functional architecture of macaque monkey visual cortex. Proc R Soc Lond B Biol Sci 198:1-59. CrossRef Medline

Irvin GE, Norton TT, Sesma MA, Casagrande VA (1986) W-like response properties of interlaminar zone cells in the lateral geniculate nucleus of a primate (Galago crassicaudatus). Brain Res 362:254-270. CrossRef Medline

Irvin GE, Casagrande VA, Norton TT (1993) Center/surround relationships of magnocellular, parvocellular, and koniocellular relay cells in primate lateral geniculate nucleus. Vis Neurosci 10:363-373. CrossRef Medline

Jin J, Wang Y, Swadlow HA, Alonso JM (2011) Population receptive fields of $\mathrm{ON}$ and OFF thalamic inputs to an orientation column in visual cortex. Nat Neurosci 14:232-238. CrossRef Medline

Kaplan E, Shapley RM (1986) The primate retina contains two types of ganglion cells, with high and low contrast sensitivity. Proc Natl Acad Sci U S A 83:2755-2757. CrossRef Medline

Kim IJ, Zhang Y, Yamagata M, Meister M, Sanes JR (2008) Molecular identification of a retinal cell type that responds to upward motion. Nature 452:478-482. CrossRef Medline

Lachica EA, Casagrande VA (1992) Direct W-like geniculate projections to the cytochrome oxidase (CO) blobs in primate visual cortex: axon morphology. J Comp Neurol 319:141-158. CrossRef Medline

Lee BB, Creutzfeldt OD, Elepfandt A (1979) The responses of magno- and parvocellular cells of the monkey's lateral geniculate body to moving stimuli. Exp Brian Res 35:547-557. Medline

Lee BB, Pokorny J, Smith VC, Martin PR, Valberg A (1990) Luminance and chromatic modulation sensitivity of macaque ganglion cells and human observers. J Opt Soc Am A 7:2223-2236. CrossRef Medline

Lennie P, Movshon JA (2005) Coding of color and form in the geniculostriate visual pathway. J Opt Soc Am A Opt Image Sci Vis 22:2013-2033. CrossRef Medline

Leventhal AG, Schall JD (1983) Structural basis of orientation sensitivity of 
Cat Retinal Ganglion cells. J Comp Neurol 220:465-475. CrossRef Medline

Levick WR (1967) Receptive fields and trigger features of ganglion cells in the visual streak of the rabbits retina. J Physiol 188:285-307. Medline

Levick WR, Thibos LN (1982) Analysis of orientation bias in cat retina. J Physiol 329:243-261. Medline

Levitt JB, Schumer RA, Sherman SM, Spear PD, Movshon JA (2001) Visual response properties of neurons in the LGN of normally reared and visually deprived macaque monkeys. J Neurophysiol 85:2111-2129. Medline

Mardia KV, Jupp PE (2000) Directional statistics. New York: Wiley.

Marrocco RT, McClurkin JW, Young RA (1981) Spatial properties of superior colliculus cells projecting to the inferior pulvinar and parabigeminal nucleus of the monkey. Brain Res 222:150-154. CrossRef Medline

Mishkin M, Ungerleider LG, Macko KA (1983) Object vision and spatial vision: two cortical pathways. Trends Neurosci 6:414-417. CrossRef

Naka K-I, Rushton WA (1966) S-potentials from colour units in the retina of fish (Cyprinidae). J Physiol 185:536-555. Medline

Norton TT, Casagrande VA (1982) Laminar organization of receptive-field properties in lateral geniculate nucleus of bush baby (Galago crassicaudatus). J Neurophysiol 47:715-741. Medline

Paik SB, Ringach DL (2012) Link between orientation and retinotopic maps in primary visual cortex. Proc Natl Acad Sci U S A 109:7091-7096. CrossRef Medline

Passaglia CL, Troy JB, Rüttiger L, Lee BB (2002) Orientation sensitivity of ganglion cells in primate retina. Vision Res 42:683-694. CrossRef Medline

Piscopo DM, El-Danaf RN, Huberman AD, Niell CM (2013) Diverse visual features encoded in mouse lateral geniculate nucleus. J Neurosci 33:46424656. CrossRef Medline

Rodieck RW, Watanabe M (1993) Survey of the morphology of macaque retinal ganglion cells that project to the pretectum, superior colliculus, and parvicellular laminae of the lateral geniculate nucleus. J Comp Neurol 338:289-303. CrossRef Medline

Schiller PH, Koerner F (1971) Discharge characteristics of single units in superior colliculus of the alert rhesus monkey. J Neurophysiol 34:920936. Medline

Schmielau F, Singer W (1977) The role of visual cortex for binocular interactions in the cat lateral geniculate nucleus. Brain Res 120:354-361. CrossRef Medline

Sclar G, Maunsell JH, Lennie P (1990) Coding of image contrast in central visual pathways of the macaque monkey. Vision Res 30:1-10. CrossRef Medline

Shou TD, Leventhal AG (1989) Organized arrangement of orientationsensitive relay cells in the cat's dorsal lateral geniculate nucleus. J Neurosci 9:4287-4302. Medline

Sillito AM, Cudeiro J, Murphy PC (1993) Orientation sensitive elements in the corticofugal influence on centre-surround interactions in the dorsal lateral geniculate nucleus. Exp Brain Res 93:6-16. Medline

Simpson JI (1984) The accessory optic system. Annu Rev Neurosci 7:13-41. CrossRef Medline

Sincich LC, Park KF, Wohlgemuth MJ, Horton JC (2004) Bypassing V1: a direct geniculate input to area MT. Nat Neurosci 7:1123-1128. CrossRef Medline

Sincich LC, Adams DL, Economides JR, Horton JC (2007) Transmission of spike trains at the retinogeniculate synapse. J Neurosci 27:2683-2692. CrossRef Medline

Skottun BC, De Valois RL, Grosof DH, Movshon JA, Albrecht DG, Bonds AB (1991) Classifying simple and complex cells on the basis of response modulation. Vision Res 31:1079-1086. Medline

Smith EL 3rd, Chino YM, Ridder WH 3rd, Kitagawa K, Langston A (1990) Orientation bias of neurons in the lateral geniculate nucleus of macaque monkeys. Vis Neurosci 5:525-545. CrossRef Medline

Solomon SG, White AJ, Martin PR (1999) Temporal contrast sensitivity in the lateral geniculate nucleus of a New World monkey, the marmoset Callithrix jacchus. J Physiol 517:907-917. CrossRef Medline

Solomon SG, White AJ, Martin PR (2002) Extraclassical receptive field properties of parvocellular, magnocellular and koniocellular cells in the primate lateral geniculate nucleus. J Neurosci 22:338-349. Medline

Solomon SG, Lee BB, Sun H (2006) Suppressive surrounds and contrast gain in magnocellular-pathway retinal ganglion cells of macaque. J Neurosci 26:8715-8726. CrossRef Medline

Solomon SG, Tailby C, Cheong SK, Camp AJ (2010) Linear and non-linear contributions to the visual sensitivity of neurons in primate lateral geniculate nucleus. J Neurophysiol 104:1884-1898. CrossRef Medline

Soodak RE, Shapley RM, Kaplan E (1987) Linear mechanism of orientation tuning in the retina and lateral geniculate nucleus of the cat. J Neurophysiol 58:267-275. Medline

Sun H, Smithson HE, Zaidi Q, Lee BB (2006) Do magnocellular and parvocellular ganglion cells avoid short-wavelength cone input? Vis Neurosci 23:441-446. Medline

Szmajda BA, Buzás P, Fitzgibbon T, Martin PR (2006) Geniculocortical relay of blue-off signals in the primate visual system. Proc Natl Acad Sci U S A 103:19512-19517. CrossRef Medline

Szmajda BA, Grünert U, Martin PR (2008) Retinal ganglion cell inputs to the koniocellular pathway. J Comp Neurol 510:251-268. CrossRef Medline

Tailby C, Solomon SG, Dhruv NT, Majaj NJ, Sokol SH, Lennie P (2007) A new code for contrast in the primate visual pathway. J Neurosci 27:39043909. CrossRef Medline

Tailby C, Solomon SG, Lennie P (2008a) Functional asymmetries in visual pathways carrying S-cone signals in macaque. J Neurosci 28:4078-4087. CrossRef Medline

Tailby C, Szmajda BA, Buzás P, Lee BB, Martin PR (2008b) Transmission of blue $(S)$ cone signals through the primate lateral geniculate nucleus. J Physiol 586:5947-5967. CrossRef Medline

Tailby C, Dobbie WJ, Hashemi-Nezhad M, Forte JD, Martin PR (2010) Receptive field asymmetries produce color-dependent direction selectivity in primate lateral geniculate nucleus. J Vis 10(8):1-18. CrossRef Medline

Tailby C, Cheong SK, Pietersen AN, Solomon SG, Martin PR (2012) Colour and pattern selectivity of receptive fields in superior colliculus of marmoset monkeys. J Physiol 590:4061-4077. CrossRef Medline

Usrey WM, Reid RC (2000) Visual physiology of the lateral geniculate nucleus in two species of New World monkey: Saimiri sciureus and Aotus trivirgatus. J Physiol 523:755-769. CrossRef Medline

Vaney DI, Sivyer B, Taylor WR (2012) Direction selectivity in the retina: symmetry and asymmetry in structure and function. Nat Rev Neurosci 13:194-208. Medline

Venkataramani S, Taylor WR (2010) Orientation selectivity in rabbit retinal ganglion cells is mediated by presynaptic inhibition. J Neurosci 30 : 15664-15676. CrossRef Medline

Vidyasagar TR, Urbas JV (1982) Orientation sensitivity of cat LGN neurones with and without inputs from visual cortical areas 17 and 18. Exp Brain Res 46:157-169. Medline

Vidyasagar TR, Pei X, Volgushev M (1996) Multiple mechanisms underlying the orientation selectivity of visual cortical neurones. Trends Neurosci 19:272-277. CrossRef Medline

Wang W, Jones HE, Andolina IM, Salt TE, Sillito AM (2006) Functional alignment of feedback effects from visual cortex to thalamus. Nat Neurosci 9:1330-1336. CrossRef Medline

Warner CE, Goldshmit Y, Bourne JA (2010) Retinal afferents synapse with relay cells targeting the middle temporal area in the pulvinar and lateral geniculate nuclei. Front Neuroanat 4:8/1-8/16. Medline

White AJ, Goodchild AK, Wilder HD, Sefton AJ, Martin PR (1998) Segregation of receptive field properties in the lateral geniculate nucleus of a New-World monkey, the marmoset Callithrix jacchus. J Neurophysiol 80:2063-2076. Medline

White AJ, Solomon SG, Martin PR (2001) Spatial properties of koniocellular cells in the lateral geniculate nucleus of the marmoset Callithrix jacchus. J Physiol 533:519-535. CrossRef Medline

Xu X, Ichida JM, Allison JD, Boyd JD, Bonds AB, Casagrande VA (2001) A comparison of koniocellular, magnocellular and parvocellular receptive field properties in the lateral geniculate nucleus of the owl monkey (Aotus trivirgatus). J Physiol 531:203-218. CrossRef Medline

Xu X, Ichida J, Shostak Y, Bonds AB, Casagrande VA (2002) Are primate lateral geniculate nucleus (LGN) cells really sensitive to orientation or direction? Vis Neurosci 19:97-108. Medline

Yukie M, Iwai E (1981) Direct projection from the dorsal lateral geniculate nucleus to the prestriate cortex in macaque monkeys. J Comp Neurol 201:81-97. CrossRef Medline 